\title{
Mechanisms and Pedagogical Counterforces of Young People's Social Exclusion: Some Remarks on the Requisites of Social Sustainability
}

\author{
Juha Hämäläinen ${ }^{1,2,3, *}$ and Pasi Matikainen ${ }^{1, *}$ \\ 1 Department of Social Sciences, University of Eastern Finland, P.O. Box 1627, 70211 Kuopio, Finland \\ 2 School of Social Development and Public Policy, Centre for Child Protection Research, Fudan University, \\ 220 Handan Road, 200433 Shanghai, China \\ 3 Faculty of Social Studies, University of Ostrava, Fr. Šrámka 3, 70900 Ostrava-Mariánské Hory, \\ Czech Republic \\ * Correspondence: juha.hamalainen@uef.fi (J.H.); pasi.k.matikainen@student.jyu.fi (P.M.); \\ Tel.: +358-50-593-9415 (J.H.); +358-40-589-3763 (P.M.)
}

Received: 15 May 2018; Accepted: 22 June 2018; Published: 25 June 2018

\begin{abstract}
This paper is focused around the concept of social exclusion and its underlying factors. Social exclusion-just as its opposite, social inclusion-is seen as a relationship between an individual's life course and society. In modern society, this relationship becomes ever more complex, increasing the probability of social exclusion. This complexity will be discussed from the viewpoint of socialization of young people. Education, employment, and citizenship are regarded as fundamental determinants of social exclusion. This paper constructs a novel theoretical understanding of the phenomenon of social exclusion and its pedagogical counterforces within the framework of social sustainability through philosophical conceptual analysis. The problem field is based on the example of Finland, where social exclusion of young people has become an important issue in political debate, despite the population's extensive social rights. In conclusion, the importance of holistic-systemic modeling is highlighted as a foundation for an integrated and coordinated system of political and educational interventions. Pedagogical counterforces against social exclusion are discussed particularly in the light of the concept of social sustainability.
\end{abstract}

Keywords: social exclusion; social inclusion; socialization; risk and protective factors; prevention of social exclusion; pedagogical strategies; policy strategies; labor market; education; citizenship

\section{Introduction}

Social exclusion has been increasingly identified as a significant economic issue especially in Europe [1], globally from the perspective of health [2], and is also reflected strongly in the United Nations' AGENDA 2030 [3,4]. Rather than the economic perspective, this article discusses the mechanisms of social exclusion of young people in today's societies, shaped by diverse processes of social change in terms of conceptual analysis and philosophical reflection and reasoning. The aim is to understand, rather than simply to predict, the phenomenon of young people's social exclusion through identification and critical analysis of the mechanisms of social exclusion and the pedagogical counterforces in the light of the concept of social sustainability. With eyes set at understanding, the analysis provided in this paper offers a novel insight into the multifaceted phenomenon of social exclusion as a pedagogical and political problem.

The originality and contribution of our study is to expand current academic perspectives to view social exclusion as an example of social unsustainability. In other words, eradicating social exclusion is a necessary premise for social sustainability. Further, we hope that this expansion of academic 
perspective-i.e., integration of social exclusion under social sustainability-also transfers to increased social-political attention given to social exclusion of future generations as being a constituent of a larger agenda. Finally, we believe that this novel contribution paves the way to a new standpoint to and endows meaningful and effective information for political and societal decision-making concerning social exclusion.

The paper provides a theoretical perspective on the role of education in a socially sustainable development. As is well known, education is a critical factor of economic sustainability through its capacity to produce human capital; increasing individual abilities, skills, and knowledge are necessary for economic growth [5-7]. However, the role of education in furthering social sustainability-social cohesion, stability, participation and trust-has been less analyzed (see e.g., [8]). Education is interpreted as a key element of sustainable social development through its capacity to promote social capital (see e.g., [9]) (In this context it is noteworthy to mention the critique of Daly \& Silver [10] (pp. 563-564), stating that the increase of social capital will not always reduce social exclusion). Building social capital through education requires being part of society, not excluded from it. As human capital contributes to societal economic sustainability, correspondingly social capital as a shared endeavor also contributes to the common good.

As noted above, social exclusion of young people exemplifies the very antithesis of social sustainability. Social scientists have been ardently investigating inequality and its implications for sustainable societies. Presenting social exclusion as an essential part of sustainability sheds additional light on analyzing the boundary conditions for sustainability. Although inequality and social exclusion have much in common, they are still different concepts; in our analysis social exclusion can be interpreted largely as a consequence of collective failure to tackle the problem of inequality effectively.

Social exclusion of young people indicates the failure of society to create sustainable conditions. This failure has economic and social consequences, as well as a diminishing effect on social cohesion and trust, thus influencing people's well-being and life orientation, which undermine the social aspect of sustainability.

This paper is divided into four parts. Part one (Section 3) introduces social inclusion as consistency and social exclusion as a discrepancy in the relationship between an individual and society. Furthermore, it discusses causes, expressions, and consequences of social exclusion of young people, while considering the role of education in endeavors of prevention and alleviation. Part two (Section 4) reflects the Finnish experience. Part three (Section 5) models the mechanisms of young people's social exclusion through the lens of social sustainability. Finally, part four (Section 6) concludes this paper by highlighting the importance of holistic-systemic modeling as a way toward a more inclusive and responsible society.

\section{Methodology}

This paper seeks to articulate a conceptual and holistic understanding of how social exclusion of young people, and the effectiveness of pedagogical interventions as counterforces to social exclusion and unsustainability, are interrelated with the phenomenon of social sustainability. This articulation emerges from a philosophical conceptual analysis of and reflections upon the key notions and relations based on existing academic literature as well as available empirical and statistical data, using Finland as a case example. Regarding Finland, existing statistical and empirical data, and political documents are analyzed to gain an understanding of the phenomenon of young people's social exclusion mechanisms and counter mechanisms. Finally, these findings are assigned integratively in the framework of social sustainability in order to build tentative holistic-systemic modeling for prevention and alleviation of the social exclusion of the young, with particular emphasis and consideration on pedagogical interventions.

The analysis used is considered to be a methodological variant of the grounded theory approach to construct an extensive conceptual and theoretical frame of reference (see [11,12]). In grounded theory, it is common to use existing data sets—in our case both qualitative and quantitative data-to develop new and revised theoretical understanding, a robust explanation of social phenomena, from otherwise fragmentary evidence, and equivocal interpretations and usage of different concepts. This kind of 
investigation within the spheres of social exclusion and social sustainability is deemed necessary because of the definitional elusiveness of these concepts in both academic research and policy-making (see $[13,14])$.

\section{Social Exclusion: Phenomenon, Concept, Alleviation}

\subsection{Characteristics of Society at the Beginning of the 21st Century}

The late stage of modernization is characterized by an information-intensive era based on highly skilled professionalism and lifelong learning. This kind of high-tech society provides new opportunities, but also presents new challenges to the young generation. Society is changing rapidly, and is becoming increasingly complex. Due to this, socialization falls apart, and the discrepancies between individuals and society proliferate significantly in today's societies. Modern lifestyle is characterized by increasing individualization, pluralism, and short-sightedness (see e.g., [15]). An increasing number of young people seem to have difficulties in integrating into society.

Today's societies are impacted by many different social and cultural factors associated with political and economic structures. Social change manifests itself, and is influenced by a changing labor market, increasing the importance of education in the life course of people, new kinds of opportunities for dealing with information offered by the development of ICT and the increasing instability and complexity of people's everyday life (see e.g., [16] (pp. 1, 4-6), [17]).

Social scientists have produced many apt and accurate characterizations of the nature of late-modern society. It has been called, for example, a post-industrialized service society (e.g., [18-21]), information society (e.g., [19,22-24]), a learning society—even a lifelong learning society (e.g., [25]), and a society based on high professional qualities (e.g., [26]). Furthermore, it has been characterized in terms of consumerism, pluralism, and individualism as well as a risk society, in which new kinds of social risks occur (e.g., [27-29].

The structural changes of the nature of the labor market have been identified and documented in many country-specific and more general studies. It has been stated that in recent years attention has focused increasingly to whether or not changes in the labor market "have precipitated a fundamental transformation in the industrial-relations systems of different countries" [30] (p. 1). Along with the development of information technologies, considerations have been focused, among other things, on the impacts of ICT (e.g., [31]). Over 30 years, throughout the industrial countries, jobs in traditional industries have been decreasing significantly and, correspondingly, increasing in the service sector. In many countries, two different fields of the labor market have been formed. On the one hand, there is a market for well-paid labor for well-educated people, and on the other hand, there is a market of low-salary work. Moreover, according to McKinsey Global Institute [32], it is estimated that in 2030 "as many as 375 million workers globally (14 percent of the global workforce) will likely need to transition to new occupational categories and learn new skills, in the event of rapid automation adoption." If this "transition to new jobs is slow, unemployment could rise and dampen wage growth" [32] (p. 1).

Due to the structural changes of the labor market, long-term unemployment has become a permanent part of the modern trade system (see e.g., [33,34]). There is a distinct correlation between low education and long-term unemployment [35]. In addition to the fact that education and the labor market are increasingly intertwined, the nature of work has been changing. This change, for its part, is connected with the change of the nature of society, concerning people's living conditions, everyday life, social roles and their identity as citizens.

There are many signs indicating that the change of social structures caused by late-modernization both offers new opportunities for employment, and causes unemployment. However, it often brings, although perhaps not necessarily, growing income differences and causes polarization in people's living conditions, well-being, and health. The concept of social exclusion refers to an individual's life course in which he/she does not find his/her place as a member of society (e.g., [2,36]). It manifests itself as 
long-term unemployment, poverty, poor education, low-level living conditions, even homelessness and other corresponding forms of marginalization (e.g., [37] (pp. 1-2), [38,39] (p. 13)).

\subsection{Social Exclusion as a Relation Phenomenon}

The concepts of social inclusion and social exclusion are not exact (e.g., [39] (p. 21), [40] (pp. 479-480). It is possible to define the terms from different perspectives, emphasizing different aspects of the phenomena. However, it is also possible to say something about the nature of the reality which the concepts refer to. It makes sense to define social inclusion and social exclusion as opposites (e.g., [41]) (Some critique of this polarization of social inclusion and exclusion can be found, e.g., in Spandler [42]; Sells, Stayner, and Davidson [43]; see also Higuchi [44]). Hence, defining one of them entails the definition of the other one as well. Correspondingly, the concepts indicate an opposite property of society: The more social exclusion, the less social inclusion in society. Accordingly, the more social exclusion occurs, the lower the level of social cohesion is; and conversely, the less there is social exclusion, the higher is the level of social cohesion.

The concept of social exclusion refers, per se, to a discrepancy between an individual and the society (Silver and Miller [45] (p. 3) refer to rupturing of the social bond that is crucial within the context of the social contract between citizens and the state). In today's society, this discrepancy manifests itself as growing occupational demands. The know-how required in working life can only be achieved through long-term education and, due to the rapid change of working life, the relevant know-how must be updated continually. Inability to meet these requirements causes an accumulation of disadvantages (see [34]). Concerning an individual's life course, it is reasonable to define social exclusion rather as a process than only as a state of affairs-a negative cycle in an individual's life course (see e.g., [46] (pp. 3-4)). There is ample evidence showing that social exclusion often intertwines with trans-generational processes (e.g., [47]).

Referring to the relationship between an individual and society as a process, which occurs within a person's lifetime, the term of social inclusion/exclusion applies to both individual and social states of affairs. The amount of social exclusion can be introduced as a number of individuals experiencing social exclusion, which also characterizes the nature of society regarding the level of social cohesion. In addition to quantitative definitions, attention can be paid to the qualitative varieties of social exclusion, both at an individual level and concerning the nature of society (cf. [48] (p. 87).

Although the aspect of inter-generational transmission of social exclusion has been identified (e.g., [49-52]), it is important to stress-particularly from an educational viewpoint-that social exclusion is not an inborn characteristic of an individual. As a process, it is connected with individual life course although it is not about an individual feature but concerns the relationship between an individual and society. It is not an "either-or" but a "more-or-less" phenomenon [53]. Risks and preventive factors have been established through research. In this sense, social exclusion can be prevented and alleviated through appropriate intervening activities (e.g., [54-56]).

Despite the confusion and ambiguity surrounding the concept of social exclusion (e.g., [57] (p. 170)), it has been used widely in political and academic debates by individual European countries. The European Union has had a significant role in establishing the concepts of social exclusion and social inclusion in the political rhetoric [58]. For example, in the UK, the concept of social exclusion has also been found to be applicable to the development of the social service system [59]. The concept of social exclusion seems to be politically viable, although it has proved to be challenging for academic use (see e.g., [60] (pp. 7-28)).

However, there is a rather significant amount of research on the phenomenon called social exclusion. We have a relatively good understanding of its origins, expressions, and consequences, both in individuals and in society. In research, attention is paid to identifying micro- and macro-social aspects, and risk and protective factors (see e.g., [2,39,40,46,61-65]). However, despite the many-sided research and theory building on the phenomenon, it has been challenging to find adequate means, political and professional, for prevention and alleviation (e.g., [48] (p. 88)). 
The mechanisms of social exclusion can be very different in different societies. For example, it has been noted that in Northern Europe, social networks are essential protective factors, but in Southern Europe the protective factor is rather the family [66]. Research-based knowledge which is valid in one country is not necessarily useful in another. For this reason, both country-specific and cross-national studies are necessary concerning the nature and mechanisms of the phenomenon itself and for the development of relevant and suitable models, strategies, and practices of prevention and alleviation for different national contexts.

\subsection{Dimensions of Social Exclusion}

According to Jyrkämä [67], the five main areas of significance for social exclusion are education, the labor market, social relationships, society's norm and value systems, and citizenship. In the tradition of research and theory-building of social exclusion, attention is paid more to exclusion from the systems of education and the labor market than from active citizenship and suitable identity as a member of society (see e.g., [10] (pp. 559-560), [68]). For both academic and political reasons, it is necessary to see the complexity of the phenomenon in which the mentioned dimensions influence each other (see [69] (p. 167)).

Social exclusion means to be socially out. Low-level education means a weak position in the labor market. In this sense, it is a platform of at least potential long-term unemployment in an individual's life course [35]. This may weaken a person's feeling of togetherness, cause passivity in social relationships, loneliness, and cultural alienation manifested as deviant behavior (see [70]). This can be conceptualized as exclusion from the common morals, social values, and generally shared norms (cf. [71]).

A lack of the feeling of belonging to society can be triggered by a weak identity as a citizen (e.g., [72,73]). From this perspective, social exclusion is a process which deprives an individual of citizenship. Manifesting itself as an insufficient feeling of togetherness with other members of society, it can be seen as being opposed to active citizenship and participation as a citizen (see [74]). This implies a distance from society's commonly shared values and norms. Crime is an extreme form of cultural exclusion.

It has been shown in one Finnish study [75] that low education, mental problems, problems in earning a living and offense behavior tend to accumulate, and that this often occurs in inter-generational processes. In the Finnish debate, social exclusion has been viewed particularly in terms of accumulation of factors causing underprivileged status, primarily as a combination of low education, long-term unemployment, life management problems, health problems and social passivity [76]. However, the cause-effect chains, also including different kinds of co-effect mechanisms, are very difficult to identify and vary significantly from one individual life course to another [44].

It makes sense, as we indicated above, to understand and define social exclusion rather in terms of 'more-or-less' than 'either-or' in the individual life course. In an individual life course, the degree of social exclusion can vary in different areas of life (see e.g., [77]). Exclusion in one area, for example educational dropout, also exposes to exclusion in other areas of life, and correspondingly, educational exclusion can result from problems in other areas. In individual life course exclusion from schooling, employment and citizenship are intertwined processes.

Furthermore, the exclusion mechanisms are unique. For example, dropping out from schooling can result primarily from personal health problems or neurological learning disability of the individual. At the same time, in such a case, the dropout rate shows that the educational system is incapable of integrating students who have certain specific health problems or learning disabilities. In that way, dropout ensues not only from personal problems but also from the weakness of the educational system and practice. (Underlying this way of thinking is the idea of "enforced social exclusion" in which opportunities for social participation are to a large extent made impossible through policy parameters of social institutions and actors (see e.g., $[78,79]$ ). In contrast to this interpretation, especially from the viewpoint of the mentally ill, see [80].) The lack of individualization and the rigidity of school environments and curricula are seen as partial causes of educational exclusion (see [81] (p. 4)). 
Concerning the complexity of cause-effect relationships and co-effect mechanisms of social exclusion, it is important to pay attention to factors at different levels of social life [82] (p. 21). In addition to individual, micro-social and macro-social factors [83], there are global forces through which national economies of individual countries are essentially shaped in today's globalizing world. Mechanisms of social exclusion are linked with the national economies, which are influenced by supranational economic forces. Global interconnectivity and moral responsibility pertaining, for example, to world poverty and social exclusion are strongly advocated (e.g., [84,85]).

However, the social exclusion of young people is not only about the mechanisms of unemployment, and it does not only concern the labor market. The phenomenon is too complex to be reduced only to economic issues. Nevertheless, the problems of young people to find a job appear to become an integral element of every modern society concerning not only the least educated, although their situation in the job market is the worst, but increasingly and more widely the whole young population.

\subsection{Risk and Protective Factors of Social Exclusion in Youth}

To identify the risk and protective factors of the social exclusion of young people, attention should be paid to the complexity of causal reasoning. Although social exclusion has been on the political agenda in Western countries for more than 30 years, the concept has remained somewhat vague, also in the sense of the rhetoric. However, it has become an essential field of political and academic activities. The significant economic consequences of and correlations with young people's exclusion partly explain the political and academic interest in this topic (see [86-89]).

Despite comprehensive research on the topic and strivings toward intervention innovations, there is very little cumulative knowledge concerning the mechanisms of social exclusion and the effectiveness of interventions [39] (pp. 13-14, 44, 120); (see also [82]). This lack of cumulative knowledge is indispensably connected with the complex multi-dimensionality of the phenomenon (For example, van Bergen et al. [90] recently developed a Social Exclusion Index Health Survey (SEI-HS) in the Netherlands in which social exclusion is understood through four dimensions: (1) "lack of social participation"; (2) "material deprivation"; (3) lack of normative integration; and (4) "inadequate access to basic social rights"). Causal explanations can be produced in various theoretical frames of reference, as well as using different research methodologies.

The problem of conceptual generality could somehow be avoided by defining the perspective more precisely, for example by speaking about learning disabilities, behavioral disorders, the misuse of intoxicants, long-term unemployment of young adults, and dropping out of second and third level schooling.

In addition to a low level of education, passivity in the labor market, economic insecurity, low social support, and insufficient institutional support all partly explain the long-term unemployment of young people [66] (Of course, these aspects also relate to the perennial debate over whether the underlying causes of poverty are structural, cultural or both (see e.g., [91])). The poverty of and different social problems suffered by the family increase the risk level significantly, and correspondingly, the parents' socio-economic status and level of education have proved to be significant protective factors [75]. Moreover, there are also many individual and society-specific risk and protective factors. Due to the case-specific nature of the cause-effect mechanisms, it is difficult to make generalizations based on exhaustive causal reasoning.

Studies have indicated that interventions blocking the long-term dropout from education and labor are particularly effective (see e.g., [92-94]). We also know well, on the basis of many studies from different countries, that the organization of adequate family support is a potent protective force against dropping out from schooling $[95,96]$. From the viewpoint of causalities, it seems plausible to focus on children's living conditions in early childhood. In other words, this is about assessing the complexity of the inter-generational transmission mechanisms of social exclusion in an individual's life course.

Already during the 1970s, poverty was explained in terms of a 'circle of deprivation', in which attention was paid to the following inter-generational cause-effect chains (e.g., [97]): 
1. Income problems of a family are associated with a poor stimulus environment of the child.

2. This results in poor studying and low school achievements, bringing about a weak position in the labor market.

3. This, for its part, causes a low economic position as an adult, which means a reduced stimulus environment for children, resulting in a deprived life course during the next generation (see also [98]).

This model expresses the importance of family as both a risk and protective factor (cf. [99]). Simultaneously, it connects the role of a family with a different kind of individual and social risk and protective factors, which makes the picture very complicated.

Risk and protective factors can be identified both in micro- and macro-social systems, as well as on the level of individual features. The disruption of the structures of socialization and excluding structures of the education system and labor market are central macro-social risk factors. The lack of social support and control by close communities (For a community-perspective to social exclusion, see [100-102]), as well as unstable conditions in a family, such as a parents' mental and intoxicant problems, low education level, unemployment, poverty, or emotional insecurity, are central micro-social risk factors. Correspondingly, a functional social-political system in terms of social benefits and services (education, family, labor, social security, youth, and health policies) can play an essential protective role on a macro-social level and in emotional security in terms of belonging to communities, the feeling of togetherness, participation and hobbies at a micro-social level (see e.g., $[100,103])$.

The social exclusion of young people is often associated with their life management problems. Multiple risk behavior has been used to illustrate the complexity of the phenomenon [104]. There is evidence for the opinion that one close relationship can be a decisive protective factor against social exclusion in a child's and young person's life course (see e.g., [105] (p. 6), [106] (p. 1)). Correspondingly, it has been noticed that some personal features can play an important role, for example optimistic life orientation (cf. [107]), and high self-esteem (cf. [89] (p. 98)) and intelligence [108].

As we have seen thus far, risk and protective factors are intertwined in complex interand co-relating long- and short-term processes in people's life courses. The impacts of risk and protective factors express themselves in a person's life history (fetus, early childhood, later childhood, early adolescence, middle adolescence, late adolescence). There are inter-generational forces as critical factors, i.e., the trans-generational accumulation of disadvantages, in terms of insufficient parenthood, depriving family relationships, and unstable living conditions. The significance of different factors varies during different phases of life. Thus, the mechanisms of risk and protection are linked with the processes of individual development, including numerous unique elements.

\subsection{Social Exclusion of Adolescents in the Context of the Life Course}

In modern society, the disarray of socialization results from the social and cultural change which manifests itself as an increasing disintegration of social life, both in different fields of social life and in the whole of society. The traditional unifying social and cultural forces make way for new lifestyles, morals, and social structures, opening up mechanisms for social exclusion in the life course, thus impairing the possibilities for a harmonious social life.

There are reasons to consider social exclusion/inclusion regarding education, the labor market, and citizenship, and to see these as three key dimensions interconnecting with each other in individuals' life courses. Therefore, it is relevant to pay attention primarily to the opportunities of young people for schooling, employment, and participation in a rapidly changing society. Educational dropout, unemployment, and social passivity are conceptualized as a failure in socialization and as manifestations of social exclusion in the context of the individual life course.

Utilizing the rather comprehensive research-based knowledge of the origins, expressions, and consequences of the social exclusion of young people, it is possible to identify the mechanisms, aiming not only to understand the nature of the phenomenon but in addition to recognize opportunities for prevention and alleviation of exclusion. Both macro- and micro-social risk and protective factors, as well as relevant individual factors, should be considered. 
Social exclusion is intimately connected with inter-generational cumulative disadvantages. Family life conditions appear to play an important role both in causing risks and protection (see e.g., [109-111]). Furthermore, adequate systems of education and services may significantly tackle social exclusion by providing support for children and young people in need (cf. [98,112]). Accordingly, impractical systems can have a negative influence on people's life courses.

Social conditions according to which people's life courses are molded vary significantly from country to country. Although there are different country-specific particularities, which must be taken into consideration in developing counterforces towards excluding mechanisms, all societies are in fact facing the challenge of the social exclusion of young people.

\subsection{Strategies for Prevention and Alleviation of Social Exclusion}

The two main lines of strategies for social welfare, political and pedagogical, are intertwined. On the one hand, political strategies focus on legislation and social institutions, and on the other hand, pedagogical strategies orientate towards educational activities [113]. Both types of interventions are relevant and necessary, complementing and benefiting from each other. As Kieselbach puts it, "enhancing" of "personal resources" and "providing more social resources" are needed in the prevention and alleviation of young people's social exclusion [66] (p. 75). Pedagogical strategies are more about contributing to personal resources, and political ones to social resources.

Cost-efficiency studies have undeniably shown that investments in care services for children and families produce multiple economic utilities [114]. This is logical. Enabling children and young people to become employed taxpayers and active citizens increases the prosperity and decreases the expenses of society, creating grounds and opportunities for a successful social and economic development. Esping-Andersen [115] calls this kind of reasoning child-centered social investment, especially characterizing the social-political system established in the Nordic countries, which is seen as a factor largely explaining the economic competitiveness and success of these countries. This philosophy expresses itself in the financial resourcing of high quality and versatile social and healthcare services and social benefits for families with children.

It has been noticed that the cost-benefit relationship of family political investments is unusually high among poor families. Positive parenting and family life have been shown to be significant protective factors against the risk behavior of children and young people (see [116-121]). It is wise to organize social-political support for families, thus strengthening their capability for supporting the sound social and emotional development of young people. In modern society, there is also the need for individually focused care services for children and young people, for example in the transition phases of their life courses within the school system [122-125].

Many kinds of programs aiming at strengthening life skills have been developed for the young who experience life management problems (e.g., [126]). However, it is meaningful to recognize the fact that it is not only a question of individual behavior, not even of an individual family. Although the importance of parents has been stated in many studies, it has also been warned that interventions should not be limited to risk families; supporting activities should cover all families [127]. Hence, attention should be paid to the opportunities for strengthening families' living conditions and parents' upbringing capacities in general.

As the mechanisms of social exclusion consist of different short-term and long-term processes, it is logical to distinguish between short-term and long-term preventing strategies. It is hard to assess the effectiveness of individual services within the system, consisting of many kinds of parallel short-term and long-term political, pedagogical and care activities. Pedagogical counterforces concern educational approaches, cultures, and methods in particular, inside and outside schooling agencies. Pedagogical research and theory-building on risk and protective mechanisms play an essential role in the development of pedagogical innovations and strategies.

Surely, regarding the nature of the phenomenon of social exclusion, on the one hand there is a need for political influence through legislation, institutions and service systems, and on the other hand 
there are good reasons to focus on pedagogical means, i.e., influencing people through upbringing and education. Efforts should be aimed at opportunities in all forms of education-formal, non-formal and informal. Furthermore, adequate social and healthcare services are needed, according to people's individual needs. There is a need for programs combining political and pedagogical innovations.

\section{The Example of Finland}

\subsection{The Finnish Social Order}

The Republic of Finland is a civilized state, a state ruled by law, and a welfare state. Each of these characterizations includes a promise to citizens. The Finnish social order is fundamentally based on the concepts of human dignity and on the responsibility of public bodies to promote human and social development aimed at well-being and caring for people's social and cultural needs. People have extensive constitutional rights in the fields of civic activities, living, social and healthcare, and education.

Democracy, equality and social justice are the central political values upon which Finnish social order is founded. Since the 1960s, society has been developed on the basis of the Nordic welfare state model, according to which the government has broad responsibility for the promotion of social welfare [128]. In the social policy literature, this social order is often called an Institutional Social Policy Model, based on the following ideas (see e.g., $[129,130]$ ):

- Principles of social security, equality, and justice

- Comprehensive social support for all, according to people's individual needs ("Need-based")

- Significant income transfers from rich to poor people ("Middle-class society")

- A comprehensive system of social benefits based on a Governmental National insurance system ("Institutionalized prevention of social and health problems")

- A wide-ranging system of public welfare services based on people's social rights ("Institutionalized welfare services")

- Extensive public welfare production

In Finland, the government is responsible for the provision of economic security and social services to all citizens according to their needs (universalism). Finnish society effects a considerable redistribution of resources from the wealthier to poorer people (income transfers). The idea of the vast responsibility of public bodies for the basic well-being of all citizens (joint responsibility through taxation) has produced a public-funded welfare system (benefits and services) financed by taxes [131]. Institutionalized economic and social rights (right to welfare), as a part of citizenship, have been prescribed in the name of social justice [132] (p. 25). This has led to the development of a strong middle class (principle of equality).

The Finnish welfare state has been developed as a national undertaking. It has been seen as an expression of a special social contract-the idea of being in the same boat. On this basis-due to substantial income transfers and comprehensive social security-Finnish society has become one of the most middle-classified countries in the world (see [133]). Contingency for this kind of development has been supported by the relatively small and homogenous population. In 2017 the population of Finland was only 5.5 million: about $88 \%$ are Finnish-speakers and $5.2 \%$ Swedish-speakers, and almost $71 \%$ of the native population belong to the Lutheran Church [134].

In general, the Finnish population is comparatively well educated, "[a] larger share of adults having attained tertiary education than in other OECD countries" [135] (p. 1). The society is also highly wired; internet access according to households is $94 \%$ [136]. Although the country is geographically relatively large in proportion to the population, the society is strongly urbanized; about $85 \%$ of the population are urban dwellers. These numbers become meaningful with regard to social exclusion when comparing with international studies. For example, although urbanization is largely considered to have significance regarding international development, it may also increase inequality, social exclusion, and polarization amongst citizens [137]. Similarly, highly wired societies appear to manifest higher 
social media usage by young people. High social media usage amongst the young has recently been linked to increased feelings of social isolation when compared to those using less social media [138]. These interesting findings in their own way underline the challenges that increasing urbanization and digitalization may pose for social inclusion, well-being and sustainability.

\subsection{Social Exclusion of Young People on Political Agenda}

In Finland, the question of the social exclusion of young people has been on the political agenda for over twenty years [139] (pp. 164-165). Over the past ten years, it has become even more pressing. Attention has been paid to the problem field in abundance, by the President of the Republic of Finland, by the Government and by top politicians. The political system at national, regional and local levels has been widely directed to the development of mechanisms of prevention and alleviation of exclusion. The intense political reaction to the increasing number of socially excluded young people becomes more understandable in the light of the Finnish social order and political values. Social exclusion of mainly young men and immigrants has been named as the most significant internal security threat to Finnish society [140,141].

According to several international comparisons, Finland is one of the top countries in education, welfare, people's happiness, the opportunities of children and young people for human development, and from a national economic point of view in international competitiveness and economic stability (e.g., [142]).

Despite this, the social exclusion of young people has been identified as a serious social problem in Finland today. Economic motive is one of the drivers behind this identification: in political debates the most used calculation sets the costs of an individual life-span exclusion to ca. 1 million euros on average [143], some estimates being even higher than this. Furthermore, in academia, there is a broad consensus about the problems of such calculations as these because of the complexity of the phenomenon of social exclusion and the variation between individual cases. However, or perhaps driven by these questions, the social exclusion of young people has become not only a political issue but also a field of research and academic debate in the forms of empirical analyses and theory building. Seeing social exclusion as a significant social problem, a considerable number of R\&D projects aiming at interventions have been funded, and both political and pedagogical innovations have been introduced [144].

Statistics indicate a remarkable expansion of the service system. The number of young people who use the welfare services has increased significantly in different fields of the service system, which can be seen to express an essential change of society. The unemployment rate of young people has for a long time been about three times higher than the national average, applying mainly to low-educated young people [144].

In 2013, the Audit Committee of the Finnish Parliament funded a study aiming at improving the impact, effectiveness and cost-efficiency measures concerning the prevention and alleviation of young people's social exclusion [58]. This report recommended development of the basic public system of services targeting young people and their families. According to the report, the best results in the prevention of the social exclusion of young people are based on a systematic and goal-oriented integrated service system containing low-threshold and case management activities. Instead of assessing and developing individual services, the creation of counterforces against social exclusion is decisively more about the whole system.

The Youth Guarantee is an example of political attempts to tackle the social exclusion of young people. In the Nordic countries, youth guarantee schemes have been applied since the 1980s as a part of the Nordic welfare model. Today, this concept is recommended by the European Union to its member countries; recently it has also been revised by the Finnish government (e.g., [145]). According to the Finnish model "[E]ach young person under 25 and recently graduated people under 30 will be offered a job, a work trial, a study place or a period at a workshop or rehabilitation, within three months of becoming unemployed". In addition "every person completing basic education will be guaranteed 
a place in general upper secondary school education, vocational education, apprenticeship training, a youth workshop, rehabilitation or a place in some other form of study" ([146] (p. 2)). Typically, the program is focused mostly on education and labor, without any particular reference to citizenship.

In a study on the experiences in Finland and Sweden of tackling young people's unemployment through the Youth Guarantee, difficulties to reach those young people who suffer from severe psychosocial problems, inadequacy for solving long-term structural problems, dependence on public policies, and the appropriate timing of interventions were identified as the most challenging factors [147]. It is apparent that the difficulties of young people to become employed are linked with the structural features of the education system and labor market, and different kinds of psychosocial problems among young people need to be considered. One further practical difficulty pertaining to the Youth Guarantee is that it cannot per se "force" an individual to participate in education or employment, that is, the individual has the possibility to decline any job or education offered by this very policy. While the moral choice of choosing social exclusion may not be considered as a case of social exclusion (in all theoretical frameworks), this does not by any means alleviate the economic costs and problems associated with social exclusion.

The available data displayed in this paper indicate how vital it is to provide individual support to avoid long-term negative consequences of young people's educational dropout, unemployment and passive orientation as citizens. These findings emphasize the structural support given to individuals, but also-at least implicitly-assume the moral responsibility of individual's choices during their life course. A particular strength of the Nordic system appears to be its effectiveness in providing individual help according to young people's individual needs. However, concurrently the fragmentation of the welfare and care service system — often driven by myopia—has been shown to hinder effective prevention and alleviation (see $[148,149])$.

\subsection{Statistical Indicators Expressing the Changing of Finnish Society}

Over the past twenty years, there have been signs of an increase in the number of young people suffering from different psychosocial problems. The availability of services relating to different disorders has substantially increased in the Finnish system of social and care services for young people (e.g., [150]). This change has been detected in several studies and reported by different professional groups working with children and young people. The statistics show, unambiguously, that the number of young people using social care services has significantly increased over the last 10-20 years. For example, the following trends are visible from the statistics (see [75]):

- The number of young adults granted disability pension owing to mental problems doubled over ten years

- Cases of children being taken into custody doubled over the past ten years (urgent actions increased by up to six-fold)

- Children as clients of the open care of child welfare have doubled over the past ten years

- Outpatient care visits of child psychiatric care have doubled, and in the youth section even tripled over the past ten years

- The number of children sent for remedial education has doubled over the past ten years

- Children living in low-income families (defined in terms of relative poverty) have tripled over the past fifteen years

Furthermore, according to the Ministry of Finance [144] (p. 24), in 2015 the percentage of early school-leavers (These are identified in the document as 18-24-year-olds with "no post-basic education qualification and who are not studying in education leading to a qualification".) in Finland was $9.2 \%$, and the number of people living at risk of social exclusion or poverty was 896,000 . Statistically speaking, these numbers indicate that the phenomenon of social exclusion as a very pressing issue.

There are, however, good reasons to ask about the nature of a society embodied in statistics. What do statistics tell us about society? What can be judged from the statistics on social exclusion? 


\subsection{The Complexity of Interpreting the Statistics}

The statistics show that Finnish society has been investing more and more in educational, social and healthcare services for children and young people, but not necessarily that the absolute needs of children and young people have increased (see [75,151]). There is space for different interpretations. We can interpret the statistics as indicating that factual problems and needs for social help among children and young people have increased, but it is also possible that the use of care services has increased for other reasons, such as the development of professional activities, for example improvements in diagnostic techniques and practices. However, due to the development of research, we know more and more about the nature of children's and young people's needs. Some changes in statistical documentation can also at least partly explain the statistics.

In any case, political interest in children's and young people's problems and needs has significantly increased in the recent past. Due to this, the resourcing of activities for prevention and alleviation of exclusion has intensified decisively. This has brought about changes in legislation, which eventually become apparent in the statistics. However, not only politicians have become more active in the area. There has also been an extensive public debate about the topics, in which the mass media has been a significant contributor. Common societal responsibility has been emphasized [152].

\subsection{Interpretations of Social Exclusion of Young People in the Finnish Media}

Different lines of discourse in the Finnish media have been identified in the debate on young people's social exclusion (see [153]): On the one hand, the social exclusion of young people has been seen to threaten society, in terms of damaging social security, economic development, and the moral order, and on the other hand, it has been viewed as a social phenomenon, because of which young people are threatened as victims. In the latter context, the social exclusion of young people has been interpreted to indicate inadequate living conditions in close relationships, especially the family, and defects in the educational system and social care services. The decline of communality mechanisms in young people's everyday life, such as informal care, support and control have been considered. Generally, the social exclusion of young people has been conceptualized in the media as symptoms of social disorder, but from many different perspectives, concerning both causes and consequences.

\subsection{Policies for Prevention and Alleviation of Social Exclusion in Finland}

The Finnish experience can be summarized by noting the remarkable position of the issues of prevention and alleviation of social exclusion of young people on the political agenda. The following points show that Finnish society has put significant effort into the theme (e.g., see [55,130,154,155]):

- Social exclusion has received particular political attention

- A significant number of projects aiming at innovations for preventing and alleviating the social exclusion of young people have been initiated since the end of the 1990s

- Development of a protective educational system and welfare services (especially child welfare, special education, youth work and psychiatric care services for children and young people) has been significant

- Professional know-how has been improved by investing in training for educators and welfare workers

- Production of research-based knowledge of the phenomenon of social exclusion and the elaboration of appropriate interventions

- Developing political strategies and programs: Education, labor and family policies, child welfare, youth policies, and improvement of welfare and social security for young people in general

- Pedagogical strategies and innovations: individual and community-based educational activities in the fields of formal and non-formal education 
Despite the numerous attempts to solve the problems and produce effective social and educational innovations, the overall phenomenon persists resiliently.

\subsection{The Outlook for Well-Being of Children and Young People in Finland}

With regard to the future, two important categories of trends of the well-being of Finnish children and young people can be identified. On the one hand, there are the trends of deterioration in protective mechanisms, consisting of decreasing supportive factors in children's growth conditions, decreasing level of adult presence in children's everyday life (see $[139,156])$, insufficient physical exercise (e.g., [157] (pp. 28-40)), [158,159], [160] (p. 90)) and sleep [161], increasing instability in family life (economic instability, high rate of divorce, inadequate feeling of togetherness) (see [139]), and increasing requirements of the achievement-based society (see [162] (p. 11)). On the other hand, there are the trends to increase research-based knowledge, improve professional know-how, and develop child and family welfare policies, legislation, and policy strategies and programs in the field of welfare work.

\subsection{Wide and Thorough Legislation}

In Finland, the child, youth, and family legislation is comprehensive and thorough. Based on systematic child-centered working orientation, it aims at prevention of risks in children's well-being. Early interventions are emphasized [89] (pp. 110-112). The legislation aims to develop an extensive and coordinated system of adequate child and youth care services under the responsibility of the local authorities.

The Child Welfare Act of 2007 [163] requires detailed statutes on methods, working processes and decision-making procedures based on child-centered working and evaluation for purposeful prevention and alleviation of social exclusion of children and young people. The Child Welfare Act also underlines support for young people's personal development and independence, promotion of young people's active citizenship and social empowerment, improvement of the quality of young people's living conditions, and principles of communality, joint responsibility, equality, multi-cultural and international orientation, healthy lifestyle, and respect for life and the environment (cf. [48] (pp. 87-88). According to the Basic Education Act of 1998 [164], students have the right to free school welfare services according to their needs. Consisting of social work, nursing and psychological services, school welfare services aim at promotion and maintenance of sound learning, good physical and mental health, and social well-being.

In Finland, young people's social exclusion is not considered primarily as an economic but as a moral issue. In the Finnish context, following the Nordic welfare model, there is extensive legislation for a citizen's civil and social rights, including children and young people. The society is committed politically and legally to promote the well-being of every individual in the name of human dignity. Promotion of social inclusion and prevention and alleviation of social exclusion are not examined primarily from the point of view of potential economic profits for society, but as a moral obligation, to which society is committed. Rather than utility calculation, the challenge is approached with respect to uncompromising political and legal normativity, although there is also an awareness of the economic utility (see page 10 above). Consequently, the statement of motives, reasoning, and justification are not based critically on economic but on moral-ideological argumentation, including the representations used to explain the nature of the phenomenon and the construction of models for a solution. Within this ideological context, social sustainability is primarily qualified on the grounds of society's capacity to fulfill its legal commitments to sustain people's well-being and social inclusion. This paper represents and stands for this tradition.

\section{Modeling the Mechanisms of Social Exclusion of Young People in the Light of the Concept of Social Sustainability}

Sustainable development or sustainability has become one of the most influential political agendas in the past three or four decades, the most recent formulation being the United Nations' Agenda 
2030 [3]. Traditionally, sustainable development has been categorized in formal UN documents through environmental, economic and social dimensions. Both the UN documents Our Common Future (1987) [165] (the so-called Brundtland Report) and The Rio declaration with its Agenda 21 (1992) [166] have been viewed as foundational in significance regarding the sustainable development agenda.

Furthermore, a very influential theoretical conceptualization-especially relevant in the business world - has been the so-called "Triple Bottom Line" (TBL) from John Elkington, first postulated in 1994 [167,168]. In 1999 Elkington referred-at least implicitly-to the three pillars of sustainable development by mentioning "economic prosperity, environmental quality and ... social justice" [169] (p. 75). Despite these prominent conceptual statements of sustainable development by the UN and Elkington, it must be noted that from a more academic point of view the environmental and economic aspects of sustainability have been dominant both in terms of scientific and practical interest from the perspectives of conceptual and theoretical development. Hence, the dimension of social sustainability has received comparatively little attention in both political and academic debates. (e.g., [170-172]).

There has been growing interest towards the social dimension of sustainability, dating approximately to the end of the 1990s [173] (p. 44). Thus, it could be claimed that the study of social sustainability is a relatively new and nascent discipline, covering only about the last twenty years. Whereas there seems to be some consensus (Writing in 2009 Dillard et al. mentioned that "At present, consensus does not exist even on a definition of social sustainability" [174] (p. 2).) relating to the key elements of the concept of social sustainability, there remain many ambiguities and different interpretations of the very concept (e.g., [175,176] (pp. 2-4), [171,177] (pp. 80-95), [178] (pp. 66-67), [12,179-181]). Hence, many scholars have seen the dimension of social sustainability to be relatively underdeveloped and undertheorized. (Some scholars have also proposed more than the traditional three pillars or dimensions of sustainability. Cultural dimension would be one of the most prominent proposals among these (e.g., [182-184], although there have been some reservations toward the very existence and the usefulness of this concept among the academia (e.g., [185] (p. 215)). For example, the expert report by IUCN The Future of Sustainability [186] does not make any distinction between social and the cultural sustainability. Furthermore, the dimension of institutional sustainability has been seen as a relevant aspect of the whole spectrum of sustainability discourse (e.g., [187]).) The same definitional equivocality is present in the concept of social exclusion [188].

Why, then, should the social aspect of sustainability be taken so seriously within the realm of sustainable development and future societies? We think one of the most insightful answers to this question comes from Ken Peattie:

When most people consider 'sustainability', they tend to think first of environmental problems related to climate change, pollution, deforestation or species loss. This apparently places it in the realms of environmental science and of environmental scientists. Yet in reality there is no such thing as 'environmental problem'. The environment does not have problems; it just is. It is society that has problems due to the unsustainable interactions between our social, economic and technological systems and the physical environment. Ultimately, sustainable development is a social phenomenon ... [189] (p. 21)

So, what then is social sustainability? What does it entail? How should it be viewed or understood? As mentioned above, there are myriads of definitions available in the academic literature. For example, one of the earliest definitions of social sustainability comes from Ignacy Sachs, who highlighted the fundamental values of equity and democracy, where democracy refers primarily to the authentic appropriation of all human rights by all citizens [190] (p. 27). Mario Polese and Richard Stren conceptualized social sustainability instead as development or growth compatible with the harmonious existence and evolution of civil society, embracing cultural and social pluralism, social integration, and advancements in the quality of life for all population segments [191] (pp. 15-16). Social sustainability has also been defined in terms of identifying the challenges for functioning that societies face in the long-term, and perhaps even more importantly, determining the minimal long-term developmental, social requirements for sustainability (i.e., critical social capital) [192] (p. 6). 
If our aim is-be it in close range or in the long haul—to envision and develop future societies that are socially sustainable, they must be at least minimally regarded as inclusive, participative, just, and responsible. If this is what minimally socially sustainable society looks like, there is considerable overlap between socially sustainable and social inclusion/exclusion. Another way to state this is to view social inclusion as a necessary but not a sufficient condition of social sustainability.

Regarding the employment/unemployment axis there is a fascinating insight given by Beate Littig and Erich Griessler, who highlighted the critical link between work and sustainability:

Work — in the broadest sense (paid and unpaid labor, care work) — plays a central role for sustainability, since the satisfaction of needs, and thus the exchange between society and nature, involves mainly some sort of work. [193] (p. 71)

Furthermore, they flesh out their concept of social sustainability as signifying "the nature-society relationships, mediated by work, as well as relationships within the society". This means that socially sustainable societies should be characterized by the satisfaction of "an extended set of human needs", the preservation of nature's "reproductive capabilities", and the fulfillment of "social justice, human dignity, and participation." [193] (p. 72).

There is increasing evidence that unemployment and job loss is a significant factor concerning declines in health, well-being and social aspects of human life. Effects thereof include social withdrawal, decreased interest in civic participation, and various immediate and trans-generational socioeconomic elements (e.g., [194-196] (pp. 17-23)). Therefore, unemployment can be a great hindrance towards the development of socially sustainable societies and a sustaining factor for social exclusion, especially for young people and the coming generations.

Apart from the labor market, there are other important considerations, especially pedagogical ones, for diminishing social exclusion and increasing social sustainability. As stated earlier (page 8), pedagogical counterforces are in this paper defined as educational approaches tackling social exclusion and promoting social inclusion and social sustainability via educational approaches, methods and cultures in different educational contexts. For example, a Triple Bottom Line-based model has been proposed and implemented in Swaziland toward ensuring socialization of orphan children into mainstream society and thus diminishing social exclusion of citizens [197]. From a pedagogical viewpoint, implementing cultural sustainability in education has been supportive of children's and youth's social everyday encounters at the micro-level and has also furthered their identity development [198]. Moreover, within the schooling system, providing care, respect and support to young people and empowering them as well as challenging their capacities and competencies cognitively and socially, are vital for cultivating just and active citizenship in young individuals (see [199,200]).

Further pedagogical counterforces aimed toward decreasing young people's social exclusion within the broader framework of the sustainability discourse are increasing educational democracy, dialogue, and participativeness (see [201,202]). For educational pedagogy to be effective regarding sustainability and justice, it has been identified as essential to include students' understanding of complex global interconnectivity as well as using both holistic and individual pedagogical perspectives strategically in formal school settings (see [203]). Furthermore, these goals of sustainable societies, social justice and participative and inclusive citizenship are all compatible with the Maastricht global education agenda [204]. All the pedagogical counterforces and ideas are aimed at increasing personal resources of young individuals to learn and cultivate in themselves the more just and moral interpersonal civic agency that is of pivotal importance for the very possibility of socially inclusive and sustainable future societies.

Therefore, the role of education in sustainable social development does not become simplified as a micro-social phenomenon only. The concept of social sustainability provides a comprehensive perspective for pedagogical modeling of the mechanisms of young people's social exclusion as an entirety of intertwining micro-, meso- and macro-social factors shaping people's life courses 
as students, employees, and citizens. We argue that more effort should be targeted at developing pedagogical strategies from the viewpoint of democratic citizenship and civic abilities in the holistic framework of social sustainability.

Finally, it is essential to recognize the correlation between parents' socioeconomic status (SES) and academic success and educational dropouts of the young. There is evidence that children coming from higher SES families tend to exhibit better academic success [205-207], have fewer educational dropouts (see e.g., [208,209]), and demonstrate more successful career aspirations [210,211] compared to those individuals coming from lower SES backgrounds. It is also worth mentioning that supportive and effective pedagogical and social strategies and programs, such as small schools and class sizes, after school programs, and early childhood education "have been found to be important factors in reducing the achievement gap between children of the 'have' and 'have-nots'" and as countermeasures against "an intergenerational cycle of school failure because of family SES" [212] (p. 446). We argue that the extended framework of social sustainability-exemplified by the above definitions of and pedagogical reflections on social sustainability-offers an integrative and more effective viewpoint from which it is possible to see more clearly the vast interconnectedness of the mechanisms and counter mechanisms that make up the phenomenon of social exclusion. Pedagogical counterforces arising from more extensive understanding of the interconnected mechanisms of social exclusion within the perspective of social sustainability are thus clearly effective and necessary for socially sustainable societies. Implicit in this argument is the conjecture that current understandings and policies for alleviating social exclusion are too narrow and myopic.

\section{Conclusions}

We will conclude by paying attention to the importance of holistic-systemic modeling and discussing opportunities to move towards a non-excluding society. We will end by briefly considering the concept of responsible society.

\subsection{Need for Holistic-Systemic Modeling}

The example of Finland shows that despite tremendous investments-both politically and educationally-the phenomenon of the social exclusion of young people stubbornly remains a constant problem of modern society. Society is not entirely at a loss what to do, but the complexity of the phenomenon requires many kinds of simultaneous and parallel prevention and alleviation activities. For the sake of critical scrutiny, it might be possible that many Finnish interventions-regardless of their good intentions - do not work or are not realized in the intended way in the life courses of socially excluded young people, or those at risk of social exclusion. Thus, these interventions might be the result of, or be frustrated because of, too narrow pedagogical perspectives or, sadly, insincere political rhetoric. Furthermore, in some Finnish political reform documents (e.g., [144]) cited in this paper, whereas there is serious consideration about the problematic reality of social exclusion, very little, if any, attention is paid to social exclusion in the form of citizenship and civic participation. Therefore, in light of these considerations, Holistic-systemic modeling of the phenomenon and interventions is needed for creating a more integrated and coordinated system of political and pedagogical strategies (see $[68,213]$ ). This need is further exemplified by the results of a recent Finnish study which argued that the processes of social segregation and exclusion are growing even within a Nordic welfare state, and that schools are not immune to socio-economic polarization [214]. That is why education, employment, and citizenship are interrelated key elements of an effective holistic modeling of tackling social exclusion. This paper offers an extensive tentative framework of social sustainability for thinking through these burning societal issues. In relation to many previous conceptualizations of alleviating social exclusion, we want to emphasize an understanding of social exclusion and its mechanisms that is more profound in depth and width.

Social exclusion has numerous and complex consequences, both in an individual's life course and in society. At a micro-social level, it often expresses itself as a state of affairs with multiple problems 
concerning living, human relationships, health, and morals. People's psychosocial problems, shown in individual life courses, are intertwined with macro-social factors, such as structural unemployment, cultural disintegration and the disarray of socialization. On a macro-social level, the consequences of social exclusion are about the conditions of social order in general.

Knowledge of causalities and the effectiveness of intervention play an essential role in the development of adequate political and pedagogical strategies [39]. Because micro- and macro-social factors intertwine within complex processes of social inclusion/exclusion, it is challenging to create models for causal explanation, and, therefore, it is difficult to systematically develop interventions for the alleviation of social exclusion and the promotion of social inclusion in people's life courses. Both country-specific and cross-national research on the topic is needed to better illuminate the complex mechanisms of the phenomenon and to develop relevant counterforces, using holistic-systemic modeling.

Successful contribution to the young generation's well-being has positive social consequences. Support for children, young people, and families with children strengthens economic and social development, the functionality of democratic social order, security and peace in society [89] (pp. 121-122, 140-141). Holistic-systemic modeling from the viewpoint of social sustainability aims to solve the problem of fragmentation and disharmony of the welfare system, expressing itself as fragmentation of information and planning, the inconsistency of development, and uncoordinated administration. Political governance of the alleviation plays an important role therein, consisting of coordinated administration, adequate legislation, and political guidance, cooperation between the public, private and third sector, as well as systematic research and development activities (see [215]). Sustainable social development, internal security and social stability consist of numerous different elements, such as the mechanisms of social exclusion and its counterforces. There are good reasons to integrate pedagogical counterforces to the political strategies and programs.

Some potential limitations of this study could be described as regional and practical in nature. There are conclusions about the necessity of integrating pedagogical counterforces to political programs and strategies. While we believe that these should apply universally, there might be practical obstacles, for example outside the Nordic welfare states or in poorer countries, to implement the necessary pedagogical resources to tackle the social exclusion of young people. Future studies should therefore focus on the feasibility and plausibility of these kinds of country- and context-specific solutions as well as on risk and protective factors of social exclusion, particularly from the perspective of the social sustainability framework. Furthermore, all the research data used in this study is, as always, incomplete and open to different interpretations. This, however, is a perpetual problem of scientific inquiry.

\subsection{Towards a Non-Excluding Society}

What is needed for a non-excluding society? Such a society may be a utopia, but there are many good reasons to strive toward it. There are several important points we should consider in fulfilling this duty, such as research on mechanisms of social exclusion, systematic development of adequate political and pedagogical strategies, investing in children and young people economically, and the concept of responsible society. Pedagogical counterforces against young people's social exclusion concern educational practices that provide intellectual, emotional and moral resistance against school dropout and unemployment and promote social participation and an active lifestyle as a citizen (see e.g., [216,217]); in this paper these aspects of educational dropout, unemployment and citizenship are all advocated not only as components of social exclusion but also as requisite considerations for a socially sustainable society.

\subsection{Responsible Society}

It is essential to consider the social exclusion of young people as a discrepancy between individuals and society. Unfortunately, it is relatively common to look at the problem in a one-sided way, as a fault of the young person, without paying attention to the role of society. We tend to ask what is wrong in the young people because they exclude themselves from society, rather than asking what is wrong 
in the society because it allows such exclusion to occur. Instead of correcting only the person, social innovations aiming to correct the society are also needed. Society is responsible for fighting against the social exclusion of young people. Education is a critical element of this struggle.

Responsible society is a non-excluding society and a socially sustainable society. We argue that first and foremost in the agenda of this kind of society should be the dignity of human beings. This moral consideration is reflected and affirmed legally, for example, in the "life of dignity" statement of "Section 19-The right to social security" in The Constitution of Finland [218] (p. 4). Could it be possible that at the heart of socially sustainable and non-excluding future societies there should be the value of human dignity rather than any other agendas? Could it be that we need to shift our political paradigm to begin at the uniqueness and dignity of each and every human life? Beginning with such a paradigm, we can then calculate other costs that are also meaningful to functioning human societies.

Author Contributions: J.H. acted as the writer of the original draft. P.M. acted as a secondary writer and editor and a reviewer of the original draft. The final manuscript is the result of both authors revising and editing the original draft. Both authors read and approved the final version.

Funding: This research received no external funding.

Conflicts of Interest: The authors declare no conflict of interest.

\section{References}

1. Nevala, A.-M.; Hawley, J.; Stokes, D.; Slater, K.; Souto Otero, M.; Santos, R.; Duchemin, C.; Manoudi, A. Reducing Early School Leaving in the EU: Executive Summary. European Parliament: Directorate General for Internal Policies; Policy Department B, Structural and Cohesion Policies: Brussels, Belgium, 2011; Available online: http://www.europarl.europa.eu/RegData/etudes/etudes/join/2011/460048/IPOLCULT_ET(2011)460048(SUM01)_EN.pdf (accessed on 30 May 2018).

2. Popay, J.; Escorel, S.; Hernández, M.; Johnston, H.; Mathieson, J.; Rispel, L. Understanding and Tackling Social Exclusion; Final Report to the WHO Commission on Social Determinants of Health from the Social Exclusion Knowledge Network; SEKN Final Report February 2008; WHO Commission on Social Determinants of Health: Geneva, Switzerland, 2008; Available online: http://www.who.int/social_determinants/ knowledge_networks / final_reports/sekn_final\%20report_042008.pdf?ua=1 (accessed on 1 May 2018).

3. United Nations. Transforming Our World: The 2030 Agenda for Sustainable Development. 2015. Available online: https://sustainabledevelopment.un.org/content/documents/21252030\%20Agenda\% 20for\%20Sustainable\%20Development\%20web.pdf (accessed on 10 November 2017).

4. Panda, R.K. Socially Exclusion and Inequality: Opportunities in Agenda 2030: Sustainable Development Goals/SDGs): Their Role in Ending Inequalities in India; A Position Paper on State of Socially Excluded Groups (SEGs) and Framework of Action; GCAP India: Delhi, India, 2016; Available online: https: / / sustainabledevelopment.un.org/content/documents/11145Social\%20exclusion\%20and\%20InequalityStudy\%20by\%20GCAP\%20India\%20.pdf (accessed on 30 May 2018).

5. Minica, M. Education-The foundation for sustainable economic development: The "respect" learning strategy principles implemented in higher economic education. Ecoforum J. 2016, 5, 17-22.

6. Nkogbu, G. Enhancing sustainable economic growth and development through human capital development. Int. J. Hum. Resour. Stud. 2015, 5, 1-18. [CrossRef]

7. Seppo, M. Fostering Sustainable Economic Growth through Human Capital Development. Statement at ECAMA Conference on 16 October 2014. Available online: http:/ / www.mw.one.un.org/fostering-sustainable-economicgrowth-through-human-capital-development/ (accessed on 6 May 2018).

8. Edvardsson Björnberg, K.; Skogh, I.; Strömberg, E. Integrating social sustainability in engineering education at the KTH Royal institute of technology. Int. J. Sustain. High. Educ. 2015, 16, 639-649. [CrossRef]

9. Helliwell, J.F.; Putnam, R.D. Education and social capital. East. Econ. J. 2007, 33, 1-19. [CrossRef]

10. Daly, M.; Silver, H. Social exclusion and social capital: A comparison and critique. Theory Soc. 2008, 37, 537-566. [CrossRef]

11. Jabareen, Y. Building a conceptual framework: Philosophy, definitions, and procedure. Int. J. Qual. Methods 2009, 8, 49-62. [CrossRef] 
12. Eizenberg, E.; Jabareen, Y. Social sustainability: A new conceptual framework. Sustainability 2017, 9, 68. [CrossRef]

13. Seaman, J. Adopting a grounded theory approach to cultural-historical research: Conflicting methodologies or complementary methods? Int. J. Qual. Methods 2008, 7, 1-17. [CrossRef]

14. Stumpf, T.S.; Sandstrom, J.; Swanger, N. Bridging the gap: Grounded theory method, theory development, and sustainable tourism research. J. Sustain. Tourism 2016, 24, 1691-1708. [CrossRef]

15. Deneen, P.J. Why Liberalism Failed; Yale University Press: New Haven, CT, USA; London, UK, 2018.

16. Newburn, T.; Shiner, M.; Young, T. Dealing with Disaffection: Young People, Mentoring and Social Inclusion; Willan Publishing: Cullompton, UK, 2013.

17. Fuchs, C. Internet and Society: Social Theory in the Internet Age; Routledge: New York, NY, USA, 2008.

18. Touraine, A. The Post-Industrial Society. Tomorrow's Social History: Classes, Conflicts and Culture in the Programmed Society; Random House: New York, NY, USA, 1971.

19. Bell, D. The Coming of Post-Industrial Society: A Venture in Social Forecasting; Basic Books: New York, NY, USA, 1973.

20. Archer, M.S. Theory, culture and post-industrial society. Theory Cult. Soc. 1990, 7, 97-119. [CrossRef]

21. Vogt, K.C. The post-industrial society: From utopia to ideology. Work Employ. Soc. 2016, 30, 366-376. [CrossRef]

22. Lyotard, J.-F. The Postmodern Condition: A Report on Knowledge; Bennington, G., Massumi, B., Trans; University of Minnesota Press: Minneapolis, MN, USA, 1984.

23. Castells, M. The Rise of the Network Society, 2nd ed.; Blackwell: Oxford, UK, 2000.

24. Webster, F. Theories of the Information Society, 4th ed.; Routledge: New York, NY, USA, 2014.

25. Hake, B.J. Lifelong learning in late modernity: The challenges to society, organizations, and individuals. Adult Educ. Q. 1999, 49, 79-90. [CrossRef]

26. Evetts, J. The sociological analysis of professionalism: Occupational change in the modern world. Int. Soc. 2003, 18, 395-415. [CrossRef]

27. Bauman, Z. Work, Consumerism and the New Poor, 2nd ed.; Open University Press: Maidenhead, UK; New York, NY, USA, 2005.

28. Giddens, A. Modernity and Self-Identity: Self and Society in the Late Modern Age; Stanford University Press: Stanford, CA, USA, 1991.

29. Beck, U. Risk Society: Towards a New Modernity; SAGE: Thousand Oaks, CA, USA, 1992.

30. Gupta, A. Structural changes in Australian labor market: 21st century. Int. J. BRIC Bus. Res. 2013, 2, 1-7.

31. Freeman, R.B. The labour market in new information economy. Oxf. Rev. Econ. Policy 2002, 18, $288-305$. [CrossRef]

32. McKinsey Global Institute. Jobs Lost, Jobs Gained: Workforce Transitions in a Time of Automation. December 2017. Available online: https:/ / www.mckinsey.com/ /media/mckinsey/featured\%20insights / future $\% 20$ of $\% 20$ organizations / what $\% 20$ the $\% 20$ future $\% 20$ of $\% 20$ work $\% 20$ will $\% 20$ mean $\% 20$ for $\% 20$ jobs $\%$ 20skills\%20and\%20wages/mgi\%20jobs\%20lost-jobs\%20gained_report_december\%202017.ashx (accessed on 5 March 2018).

33. Blien, U.; Helge, S. Structural Change and Regional Employment Development. Conference Paper. Leibniz Information Centre for Economics. 1 January 2015. Available online: https:/ / www.econstor.eu/bitstream/ 10419/113162/1/VfS_2015_pid_337.pdf (accessed on 7 May 2018).

34. Restrepo, P. Skill Mismatch and Structural Unemployment; Massachusetts Institute of Technology: Cambridge, MA, USA, 2015; Available online: https:/ / economics.mit.edu/files/11078 (accessed on 7 May 2018).

35. Garrouste, C.; Kozovska, K.; Perez, E.A. Education and Long-Term Unemployment; JRC Scientific and Technical Reports; European Commission: Luxembourg, 2010; Available online: http:/ / publications.jrc.ec.europa.eu/ repository/bitstream/JRC59305/reqno_jrc59305_eur_unemployment.pdf (accessed on 25 April 2018).

36. Sacker, A.; Ross, A.; Macleod, C.A.; Netuveli, G.; Windle, G. Health and social exclusion in older age: Evidence from Understanding Society, the UK household longitudinal study. J. Epidemiol. Commun. Health 2017, 71, 681-690. [CrossRef] [PubMed]

37. Ziyauddin, K.M. Dimensions of social exclusion: An introduction. In Dimensions of Social Exclusion: Ethnographic Explorations; Ziyauddin, K.M., Kasi, E., Eds.; Cambridge Scholars Publishing: Newcastle upon Tyne, UK, 2009; pp. 1-6. 
38. Agulnik, P.; Burchardt, T.; Evans, M. Response and prevention in the British welfare state. In Understanding Social Exclusion; Hills, J., Le Grand, J., Piachaud, D., Eds.; Oxford University Press: New York, NY, USA, 2002; pp. 155-177.

39. Levitas, R.; Pantazis, C.; Fahmy, E.; Gordon, D.; Lloyd, E.; Patsios, D. The Multi-Dimensional Analysis of Social Exclusion; Department of Sociology and School for Social Policy, University of Bristol: Bristol, UK, 2007; Available online: http:/ / dera.ioe.ac.uk/6853/1/multidimensional.pdf (accessed on 1 May 2018).

40. Morgan, C.; Burns, T.; Fitzpatrick, R.; Pinfold, V.; Priebe, S. Social exclusion and mental health: Conceptual and methodological review. Br. J. Psychiatry 2007, 191, 477-483. [CrossRef] [PubMed]

41. Levitas, R. Let's hear it for humpty: Social exclusion, the third way and cultural capital. Cult. Trends 2004, 13, 41-56. [CrossRef]

42. Spandler, H. From social exclusion to inclusion? A critique of the inclusion imperative in mental health. Med. Sociol. Online 2007, 2, 3-16.

43. Sells, D.J.; Stayner, D.A.; Davidson, L. Recovering the self in schizophrenia: An integrative review of qualitative studies. Psychiatr. Q. 2004, 75, 87-97. [CrossRef] [PubMed]

44. Higuchi, A. The mechanisms of social exclusion in modern society: The dilemma of active labor market policy (transl. A Brown). Int. J. Jpn. Sociol. 2014, 23, 110-124. [CrossRef]

45. Silver, H.; Miller, S.M. Social Exclusion. Indicators 2003, 2, 1-17. Available online: http://www. humiliationstudies.org/documents/SilverSocialExclusion.pdf (accessed on 5 May 2018).

46. Byrne, D. Social Exclusion, 2nd ed.; Open University Press: Maidenhead, UK, 2005.

47. Hobcraft, J. Social exclusion and the generations. In Understanding Social Exclusion; Hills, J., Le Grand, J., Piachaud, D., Eds.; Oxford University Press: New York, NY, USA, 2002; pp. 62-83.

48. Saunders, P. Social exclusion: Challenges for research and implication for policy. Econ. Labour Relat. Rev. 2008, 19, 73-91. [CrossRef]

49. Sigle-Rushton, W. Intergenerational and Life-Course Transmission of Social Exclusion in the 1970 British Cohort Study (February 2004). LSE STICERD Research Paper No. CASE078. 2004. Available online: https:/ / ssrn.com/abstract=1158969 (accessed on 10 May 2018).

50. Hobcraft, J. Intergenerational and Life-Course Transmission of Social Exclusion: Influences and Childhood Poverty, Family Disruption and Contact with the Police (November 1998). LSE STICERD Research Paper No. CASE015. 1998. Available online: https:/ / ssrn.com/abstract=1158906 (accessed on 9 May 2018).

51. Bynner, J. Childhood risks and protective factors in social exclusion. Child. Soc. 2001, 15, 285-301. [CrossRef]

52. Foster, H.; Hagan, J. Incarceration and intergenerational social exclusion. Soc. Prob. 2007, 54, $399-433$. [CrossRef]

53. Silver, H. The Process of Social Exclusion: The Dynamics of an Evolving Concept; Chronic Poverty Research Centre Working Paper No. 95; IDPM/Chronic Poverty Research Centre: Manchester, UK, 2007. [CrossRef]

54. SEU (Social Exclusion Unit). Preventing social exclusion: Report by the Social Exclusion Unit. 2001. Available online: http:/ / www.bris.ac.uk/poverty/downloads/keyofficialdocuments/Preventing\%20Social\% 20Exclusion.pdf (accessed on 3 May 2018).

55. PREVENT. Prevent: Tools for Preventing Social Exclusion and Increasing Well-Being in Schools; Preventing Social Exclusion of Children Cooperation Project; University of Oulu: Oulu, Finland, 2015; Available online: http:/ / www.oulu.fi/sites/default/files/Prevent_EN_web.pdf (accessed on 2 May 2018).

56. Erola, J.; Kilpi-Jakonen, E. Social Inequality across the Generations: The Role of Compensation and Multiplication in Resource Accumulation; Edward Elgar Publishing: Cheltenham, UK, 2017.

57. Rawal, N. Social inclusion and exclusion: A review. Dhaulagiri J. Sociol. Anthropol. 2008, 2, 161-180. [CrossRef]

58. Notkola, V.; Pitkänen, S.; Tuusa, M.; Ala-Kauhaluoma, M.; Harkko, J.; Korkeamäki, J.; Lehikoinen, T.; Lehtoranta, P.; Puumalainen, J. Nuorten Syrjäytyminen. Tietoa, Toimintaa ja Tuloksia? Eduskunnan Tarkastusvaliokunnan Julkaisu 1/2013; Eduskunta: Helsinki, Finland, 2013; Available online: https:/ / www.eduskunta.fi/FI/tietoaeduskunnasta/ julkaisut/Documents/trvj_1+2013.pdf (accessed on 15 March 2018).

59. Axford, N. Is social exclusion a useful concept in children's services? Br. J. Soc. Work 2010, 40, 737-754. [CrossRef]

60. Levitas, R. The Inclusive Society? Social Inclusion and New Labour, 2nd ed.; Macmillan: Basingstoke, UK, 2005.

61. Agulnik, P.; Hills, J.; Le Grand, J.; Piachaud, D. Understanding Social Exclusion; Oxford University Press: Oxford, UK, 2002.

62. Pierson, J. Tackling Social Exclusion, 2nd ed.; Routledge: New York, NY, USA, 2009. 
63. Healey, J. Poverty and Social Exclusion; Spinney Press: Thirroul, NSW, Australia, 2011.

64. Parodi, G.T.; Sciulli, D.T. Social Exclusion: Short and Long Term Causes and Consequences; Physica-Verlag HD: Heidelberg, Germany, 2012.

65. Kummitha, R.K.R. Social exclusion: The European concept for Indian social reality. Social Chang. 2015, 45, 1-23. [CrossRef]

66. Kieselbach, T. Long-term unemployment among young people: The risk of social exclusion. Am. J. Commun. Psychol. 2003, 12, 69-76. [CrossRef]

67. Jyrkämä, J. Nuoret sivuraiteelle? Nuorisosta, syrjäytymisestä yhteiskunnasta. In Suomalaista Nuorisotutkimusta; Tutkimuksia ja Selvityksiä 1; Mikkola, A., Ed.; Kansalaiskasvatuksen Keskus: Helsinki, Finland, 1986; pp. 37-58.

68. Fahmy, E. Tackling youth exclusion in the UK: Challenges for current policy and practice. Soc. Work Soc. Int. Online J. 2008, 6. Available online: http://www.socwork.net/sws/article/view/59/361 (accessed on 7 May 2018).

69. Room, G.J. Social exclusion: Solidarity and the challenge of globalization. Int. J. Soc. Welf. 1999, 8, 166-174. [CrossRef]

70. Fiske, S.; Yamamoto, M. Coping with rejection: Core social motives across cultures. In The Social Outcast: Ostracism, Social Exclusion, Rejection, and Bullying; Williams, K.D., Forgas, J.P., Hippel, W.V., Eds.; Psychology Press: New York, NY, USA, 2005; pp. 185-198.

71. Nichols, A.; Mitchell, J.; Lindner, S. Consequences of Long-Term Unemployment; The Urban Institute: Washington, DC, USA, 2013; Available online: https:/ / www.urban.org/sites/default/files/publication/ 23921/412887-Consequences-of-Long-Term-Unemployment.PDF (accessed on 10 May 2018).

72. Hall, T.; Coffey, A.; Williamson, H. Self, space and place: Youth identities and citizenship. Br. J. Sociol. Educ. 1999, 20, 502-513. [CrossRef]

73. Yuval-Davis, N. Belonging and the politics of belonging. Patterns Prejudice 2006, 40, 197-214. [CrossRef]

74. Kyei-Poku, I. The benefits of belongingness and interactional fairness to interpersonal citizenship behavior. Leadersh. Organ. Dev. J. 2014, 35, 691-709. [CrossRef]

75. Paananen, R.; Ristikari, T.; Merikukka, M.; Rämö, A.; Gissler, M. Lasten ja Nuorten Hyvinvointi Kansallinen Syntymäkohortti 1987-Tutkimusaineiston Valossa; Raportti 52/2012; Terveyden ja Hyvinvoinnin Laitos (THL): Helsinki, Finland, 2012; Available online: https:/ / www.julkari.fi/bitstream/handle/10024/102984/THL_ RAPO52_2012_web.pdf?sequence=1\&isAllowed=y (accessed on 10 April 2018).

76. Kestilä, L.; Heino, T.; Solantaus, T. Nuorten Syrjäytyminen-Epäsuotuisia Polkuja Aikuisuuteen. Haaste 1/2011. 2011. Available online: http://www.haaste.om.fi/fi/index/lehtiarkisto/haaste12011/ nuortensyrjaytyminen-epasuotuisiapolkujaaikuisuuteen.html (accessed on 15 April 2018).

77. Burchardt, T.; Le Grand, J.; Piachaud, D. Degrees of exclusion: Developing a dynamic, multidimensional measure. In Understanding Social Exclusion; Hills, J., Le Grand, J., Piachaud, D., Eds.; Oxford University Press: New York, NY, USA, 2002; pp. 30-42.

78. Burchardt, T. Social exclusion. In The Blackwell Encyclopaedia of Social Work; Davies, M., Ed.; Blackwell: Oxford, UK, 2000; pp. 320-321.

79. Boardman, J. Social exclusion and mental health-How people with mental health problems are disadvantaged: An overview. Ment. Health Soc. Incl. 2011, 15, 112-121. [CrossRef]

80. Davey, S.; Gordon, S. Definitions of social inclusion and social exclusion: The invisibility of mental illness and the social conditions of participation. Int. J. Cult. Ment. Health 2017, 10, 229-237. [CrossRef]

81. Pennacchia, J.; Thomson, P.; Mills, M.; McGregor, G. Alternative programmes, alternative schools and social justice. Crit. Stud. Educ. 2016, 57, 1-5. [CrossRef]

82. Bynner, J. Risks and Outcomes of Social Exclusion Insights from Longitudinal Data; University of London: London, UK, 2000; Available online: http:/ / www.cls.ioe.ac.uk/library-media/documents/Bynner\%202000\% 20Childhood\%20Risks\%20and\%20Outcomes\%20of\%20Social\%20Exclusion.pdf (accessed on 1 May 2018).

83. Berman, Y.; Phillips, D. Indicators of social quality and social exclusion at national and community level. Soc. Indic. Res. 2000, 50, 329-350. [CrossRef]

84. Pogge, T.W. World poverty and human rights. Ethics Int. Aff. 2005, 19, 1-7. [CrossRef]

85. Pogge, T.W. World Poverty and Human Rights: Cosmopolitan Responsibilities and Reforms, 2nd ed.; Polity Press: Cambridge, UK, 2008. 
86. Boudarbat, B.; Ajbilou, A. Youth Exclusion in Morocco: Context, Consequences, and Policies; Middle East Youth Initiative Working Paper No. 5; Wolfensohn Center for Development: Brookings: Washington, DC, USA, 2007. [CrossRef]

87. Paciello, M.C. The Political Economy of Youth Exclusion in the Mediterranean: Continuity or Change? Op-Med: Opinions on the Mediterranean (June 2012). The German Marshal Fund of the United States, 2012. Available online: http:/ / www.gmfus.org/publications/political-economy-youth-exclusion-mediterraneancontinuity-or-change (accessed on 2 May 2018).

88. Marcus, R.; Gavrilovic, M. The Impacts of the Economic Crisis on Youth: Review of Evidence (October 2010); Overseas Development Institute: London, UK, 2010. Available online: https:/ / assets.publishing.service.gov.uk/media/ 57a08b1740f0b64974000970/60828_Youth-Evidence-Review-Final.pdf (accessed on 10 May 2018).

89. SPC. Social Europe: Aiming for Inclusive Growth; Annual Report of the Social Protection Committee on the Social Situation in the European Union; Publications Office of the European Union: Luxembourg, 2015; Available online: http: / / ec.europa.eu/ social / main.jsp?catId=738\&langId=en\&pubId=7744\&visible=0 (accessed on 1 May 2018).

90. van Bergen, A.P.L.; Hoff, S.J.M.; Schreurs, H.; van Loon, A.; van Hemert, A.M. Social Exclusion Index-for Health Surveys (SEI-HS): A prospective nationwide study to extend and validate a multidimensional social exclusion questionnaire. BMC Public Health 2017, 17, 253. [CrossRef] [PubMed]

91. Jordan, G. The causes of poverty cultural vs. structural: Can there be a synthesis? Perspect. Public Aff. 2004, 1, 18-34. Available online: https:/ / www.asu.edu/mpa/Jordan.pdf (accessed on 5 March 2018).

92. Hallam, C.A. Teachers' Viewpoints of Strategies to Prevent School Exclusion: A Q Methodological Study. Ph.D. Thesis, University of Nottingham, Nottingham, UK, May 2014. Available online: http:/ /eprints. nottingham.ac.uk/27840/1/DEdApp\%20Cathy\%20Hallam\%204171043.pdf (accessed on 7 May 2018).

93. Young, J. The Effect of Work-Related Programs on Dropout Rates: A Meta-Analysis. Master's Thesis, Loyola University, Chicago, IL, USA, December 2013. Available online: http:/ / ecommons.luc.edu/luc_theses/1858 (accessed on 10 March 2018).

94. Christenson, S.L.; Thurlow, M.L. School dropouts: Prevention considerations, interventions, and challenges. Curr. Dir. Psychol. Sci. 2004, 13, 36-39. [CrossRef]

95. Strom, R.E.; Boster, F.J. Dropping out of high school: A meta-analysis assessing the effect of messages in the home and in school. Commun. Educ. 2007, 56, 433-452. [CrossRef]

96. Blondal, K.S.; Adalbjarnardottir, S. Parenting in relation to school dropout through student engagement: A longitudinal study. J. Marriage Fam. 2014, 76, 778-795. [CrossRef]

97. Holman, R. Poverty: Explanations of Social Deprivation; Martin Robertson and Company Ltd.: Oxford, UK, 1978.

98. Karhula, A.; Lehti, H.; Erola, J. Intergenerational scars? The long-term effects of parental unemployment during a depression. Res. Finn. Soc. 2017, 10, 87-99.

99. Erola, J.; Kilpi-Jakonen, E. Compensation and other forms of accumulation in intergenerational social inequality. In Social Inequality across the Generations: The Role of Compensation and Multiplication in Resource Accumulation; Erola, J., Kilpi-Jakonen, E., Eds.; Edward Elgar Publishing: Cheltenham, UK, 2017; pp. 3-25.

100. Richardson, L.; Mumford, K. Community, neighbourhood, and social infrastructure. In Understanding Social Exclusion; Hills, J., Le Grand, J., Piachaud, D., Eds.; Oxford University Press: New York, NY, USA, 2002; pp. 202-225.

101. Henderson, P. Including the Excluded: From Practice to Policy in European Community Development; The Policy Press: Bristol, UK, 2005.

102. Richardson, L. DIY Community Action: Neighbourhood Problems and Community Self-Help; The Policy Press: Bristol, UK, 2008.

103. Baumeister, R.F.; Brewer, L.E.; Tice, D.M.; Twenge, J.M. Thwarting the need to belong: Understanding the interpersonal and inner effects of social exclusion. Soc. Personal. Psychol. Compass 2007, 1, 506-520. [CrossRef]

104. Jackson, C.A.; Henderson, M.; Frank, J.W.; Haw, S.J. An overview of prevention of multiple risk behaviour in adolescence and young adulthood. J. Public Health 2012, 34, i31-i40. [CrossRef] [PubMed]

105. Magadi, M.; Middleton, S. Britain's Poorest Children Revisited: Evidence from the BHPS (1994-2002); Save The Children: London, UK, 2005.

106. Munn-Giddings, C.; Stokken, R.; Maglajilic, R.A. Editorial: Social inclusion. Intersectionalities 2015, 4, 1-6. Available online: http:/ /journals.library.mun.ca/ojs/index.php/IJ/article/view/1615 (accessed on 20 April 2018). 
107. Baumeister, R.F.; DeWall, R.F.; Ciarocco, N.J.; Twenge, J.M. Social exclusion impairs self-regulation. J. Personal. Soc. Psychol. 2005, 88, 589-604. [CrossRef] [PubMed]

108. Baumeister, R.F.; Twenge, R.F.; Nuss, J.M. Effects of social exclusion on cognitive processes: Anticipated aloneness reduces intelligent thought. J. Personal. Soc. Psychol. 2002, 83, 817-827. [CrossRef]

109. Morris, K.; Barnes, M.; Mason, P. Children, Families and Social Exclusion: New Approaches to Prevention; The Policy Press: Bristol, UK, 2009.

110. Besemer, K.L.; Dennison, S.M. Social exclusion in families affected by paternal imprisonment. Aust. N. Z. J. Criminol. 2017. [CrossRef]

111. Cochran, J.C.; Siennick, S.E.; Mears, D.P. Social exclusion and parental incarceration impacts on adolescents' networks and school engagement. J. Marriage Fam. 2018, 80, 478-498. [CrossRef] [PubMed]

112. Canali, C.; Geron, D. Poverty and Social Exclusion of Children and Families in Italy and Europe: Some Comparisons. In Theoretical and Empirical Insights into Child and Family Poverty. Children's Well-Being: Indicators and Research; Fernandez, E., Zeira, A., Vecchiato, T., Canali, C., Eds.; Springer: Cham, Switzerland, 2015; Volume 10, pp. 175-184.

113. Hämäläinen, J. Hyvinvoinnin kaksi strategiaa: Poliittinen ja pedagoginen. In Hyvinvointi Yhteiskuntapoliittisena Tavoitteena; Niemelä, P., Pursiainen, T., Eds.; Sosiaalipoliittisen Yhdistyksen Tutkimuksia Nro 62; University of Kuopio: Kuopio, Finland, 2006; pp. 16-29.

114. Sipilä, J.; Österbacka, E. Enemmän Ongelmien Ehkäisyä, Vähemmän Korjailua? Perheitä ja Lapsia Tukevien Palvelujen Tuloksellisuus ja Kustannusvaikuttavuus; Ministry of Finance: Helsinki, Finland, 2013.

115. Esping-Andersen, G. Why We Need a New Welfare State; Oxford University Press: Oxford, UK, 2002.

116. Heath, P. Parent-Child Relations: Context, Research and Application, 2nd ed.; Pearson: Hoboken, NJ, USA, 2009.

117. Rutter, M.; Giller, H.; Hagell, A. Antisocial Behaviour by Young People; Cambridge University Press: Cambridge, UK, 1998.

118. Sosic-Vasic, Z.; Kröner, J.; Schneider, S.; Vasic, N.; Spitzer, M.; Streb, J. The Association between Parenting Behavior and Executive Functioning in Children and Young Adolescents. Front. Psychol. 2017, 8, 472. [CrossRef] [PubMed]

119. Steinberg, L.; Elmen, J.; Mounts, N. Authoritative Parenting, Psychosocial Maturity, and Academic Success among Adolescents. Child Dev. 1989, 60, 1424-1436. [CrossRef] [PubMed]

120. Kawabata, Y.; Alink, L.R.A.; Tseng, W.-L.; van Ijzendoorn, M.H.; Crick, N.R. Maternal and paternal parenting styles associated with relational aggression in children and adolescents: A conceptual analysis and meta-analytic review. Dev. Rev. 2011, 31, 240-278. [CrossRef]

121. Hoeve, M.; Dubas, J.S.; Eichelsheim, V.I.; van der Laan, P.H.; Smeenk, W.; Gerris, J.R.M. The relationship between parenting and delinquency: A meta-analysis. J. Abnormal Child Psychol. 2009, 37, 749-775. [CrossRef] [PubMed]

122. Webster, C.; Simpson, D.; MacDonald, R.; Abbas, A.; Cieslik, M.; Shildrick, T.; Simpson, M. Poor Transitions: Social Exclusion and Young Adults; The Policy Press: Bristol, UK, 2004.

123. Stein, M. Young people leaving care: Transitions to adulthood. In Managing Transitions: Support for Individuals at Key Points of Change; Petch, A., Ed.; The Policy Press: Bristol, UK, 2009; pp. 25-40.

124. MacIntyre, G. Transitions for young people with learning disabilities. In Managing Transitions: Support for Individuals at Key Points of Change; Petch, A., Ed.; The Policy Press: Bristol, UK, 2009; pp. 41-58.

125. Judd, S. Young people with mental health problems. In Managing Transitions: Support for Individuals at Key Points of Change; Petch, A., Ed.; The Policy Press: Bristol, UK, 2009; pp. 59-72.

126. Devanney, C. Realistic expectations: Accounting for young people's progress in training programmes. Int. J. Public Sect. Manag. 2009, 22, 8-20. [CrossRef]

127. Churchill, H.; Clarke, K. Investing in parenting education: A critical review of policy and provision in England. Soc. Policy Soc. 2010, 9, 39-53. [CrossRef]

128. Kettunen, P. The Nordic Welfare State in Finland. Scand. J. Hist. 2001, 26, 225-247. [CrossRef] [PubMed]

129. Ministry of Social Affairs and Health. Social Welfare in Finland; Helsinki University Printing House: Helsinki, Finland, 2006; Available online: http:/ / adapt.it/adapt-indice-a-z/wp-content/uploads/2014/08/ministry_ finland_welfare.pdf (accessed on 30 May 2018).

130. Virtanen, P. Report on Social Exclusion in Finland. First Progress Report written for the European Commission, DG Employment, 2003. Available online: http:/ / ec.europa.eu/employment_social/soc-prot/ studies/finland_1st_report_final_en.pdf (accessed on 1 May 2018). 
131. Sainsbury, D. Analysing welfare state variations: The merits and limitations of models based on the residual-institutional distinction. Scand. Polit. Stud. 1991, 14, 1-30. [CrossRef]

132. Esping-Andersen, G. The Three Worlds of Welfare Capitalism; Polity Press: Cambridge, UK, 1990.

133. Haavisto, I. Vankistuva Keskiluokka; EVA-analyysi, No 63, 29.5.2018; Elinkeinoelämän Valtuuskunta (EVA): Helsinki, Finland, 2018; Available online: https:/ /www.eva.fi/wp-content/uploads/2018/05/eva_ analyysi_no_63.pdf (accessed on 20 May 2018).

134. Statistics Finland. Population Structure. 2017. Available online: http://www.stat.fi/tup/suoluk/suoluk_ vaesto_en.html (accessed on 10 April 2018).

135. OECD. "Finland”. In Education at a Glance 2017: OECD Indicators; OECD Publishing: Paris, France, 2017.

136. Eurostat. Digital Economy and Society Statistics-Households and Individuals. 2017. Available online: http: / / ec.europa.eu/eurostat/statistics-explained/index.php?title=Digital_economy_and_society_ statistics_-_households_and_individuals (accessed on 30 May 2018).

137. McGranahan, G.; Satterthwaite, D. Urbanisation Concepts and Trends; IIED Working Paper; IIED: London, UK, 2014; Available online: http:/ / pubs.iied.org/pdfs/10709IIED.pdf (accessed on 30 May 2018).

138. Primack, B.A.; Shensa, A.; Sidani, J.E.; Whaite, E.O.; Lin, L.Y.; Rosen, D.; Colditz, J.B.; Radovic, A.; Miller, E. Social media use and perceived social isolation among young adults in the U.S. Am. J. Prev. Med. 2017, 53, 1-8. [CrossRef] [PubMed]

139. Alanen, L.; Sauli, H.; Strandell, H. Children and childhood in a welfare state: The case of Finland. In Children's Welfare in Ageing Europe: Vol. 1; Jensen, A.-M., Ed.; Norwegian Centre for Child Research: Trondheim, Norway, 2004; pp. 143-209.

140. Pulkkinen, A. Syrjäytyminen on Sisäisen Turvallisuuden Suurin Uhka. Suomen Pelastusalan Keskusjärjestö (SPEK). 7 September 2015. Available online: http://www.spek.fi/news/Syrjaytyminen-on-sisaisenturvallisuuden-suurin-uhka/kih24s4q/5a8cf045-b4f9-471b-ac13-09598c8dad3f (accessed on 15 April 2018).

141. Ministry of Interior. Internal Security Strategy to Make Finland the Safest Country in the World. Press Release 105/2017. Available online: http:/ / valtioneuvosto.fi/en/article/- / asset_publisher/1410869/ sisaisen-turvallisuuden-strategia-rakentaa-maailman-turvallisinta-maata (accessed on 30 May 2018).

142. Helliwell, J.F.; Layard, R.; Sachs, J.D. World Happiness Report 2018; Sustainable Development Solutions Network: New York, NY, USA, 2018.

143. National Audit Office of Finland. Preventing Young People's Exclusion: Abstract. 2007. Available online: https: / / www.vtv.fi / files/79/1462007_Preventing_young_peoples_exclusion.pdf (accessed on 30 May 2018).

144. Ministry of Finance. Europe 2020 Strategy: Finland's National Reform Programme (Spring 2017); Ministry of Finance: Helsinki, Finland, 2017; Available online: https:/ / ec.europa.eu/info/sites/info/files/2017european-semester-national-reform-programme-finland-en.pdf (accessed on 1 June 2018).

145. Ministry of Employment and the Economy. Youth Guarantee 2013. 2012. Available online: http: / / nuorisotakuu.fi/documents /3924414/4306153/final_report2013.pdf/44fce46f-7617-42fa-b166fab04c1d79ff/final_report2013.pdf.pdf (accessed on 20 May 2018).

146. Ministry of Education and Culture. Youth Guarantee-The First Months and Next Steps. 21 May 2013. Available online: http:/ / nuorisotakuu.fi/documents/3924414/4305969/nuorisotakuu_final_en_04092013. pptx_vain_luku_.pdf/ae19b7f0-5fb0-486e-8178-3e7982b3bb15/nuorisotakuu_final_en_04092013.pptx_ vain_luku_.pdf.pdf (accessed on 5 June 2017).

147. Mascherini, M. Youth Guarantee: Experiences from Finland and Sweden; Eurofound: Dublin, Ireland, 2012; Available online: http:/ /apskills.ilo.org/ap-youthnet/resources/youth-guarantee-experiences-from-finlandand-sweden/at_download/file1 (accessed on 13 March 2018).

148. Rauch, D. Institutional Fragmentation and Social Service Variations: A Scandinavian Comparison. Ph.D. Thesis, Umeå University, Umeå, Sweden, October 2005. Available online: http:/ /www.diva-portal.org/smash/get/ diva2:143986/FULLTEXT01.pdf (accessed on 10 May 2018).

149. Champion, C.; Bonoli, G. Institutional fragmentation and coordination initiatives in Western European welfare states. J. Eur. Soc. Policy 2011, 21, 323-334. [CrossRef]

150. Rimpelä, M. Lasten ja nuorten hyvinvointi. In Suomalaisten Hyvinvointi; Moisio, P., Karvonen, S., Simpura, J., Heikkilä, M., Eds.; Stakes: Helsinki, Finland, 2008; pp. 62-74.

151. Teperi, J.; Porter, M.E.; Vuorenkoski, L.; Baron, J.F. The Finnish Health Care System: A Value-Based Perspective; Sitra Reports 82; Edita: Helsinki, Finland, 2009; Available online: https://www.hbs.edu/faculty/Publication\% 
20Files/Finnish_Health_Care_System_SITRA2009_78584c8b-10c4-4206-9f9a-441bf8be1a2c.pdf (accessed on 11 May 2018).

152. Moilanen, M. EU Year for Combating Poverty and Social Exclusion Increases Awareness of Problems and Helps Tackle Causes of Poverty (transl. M Waller). Prime Minister's Office Finland, 8 February 2010. Available online: http:/ /vnk.fi/en/artikkeli/-/asset_publisher/1271139/eu-year-for-combating-povertyand-social-exclusion-increases-awareness-of-problems-and-helps-tackle-causes-of-poverty (accessed on 12 May 2018).

153. Juppi, P. Pahoinvoivia uhreja, turvallisuusuhkia ja taloudellisia taakkoja. Nuorten syrjäytymisen tulkintakehykset suomalaisessa uutismediassa. Janus 2011, 19, 200-220.

154. Ministries of Social Affairs and Health. Poverty and Social Exclusion in Finland in the 1990s, New ed.; Ministry of Social Affairs and Health Publications: Helsinki, Finland, 1999; Available online: https://julkaisut. valtioneuvosto.fi/bitstream/handle/10024/74610/Julk199925.pdf?sequence=1 (accessed on 8 May 2018).

155. Youth Partnership. Information Template on Social Inclusion of Young People in Finland; Council of Europe: Strasbourg, France, 2014; Available online: https:/ / pjp-eu.coe.int/documents /1017981/7110690/Social+ inclusion_Finland2014.pdf/7569a11b-12ff-49c9-ba8f-7d4f9873e6f5 (accessed on 8 May 2018).

156. Rönkä, A.; Malinen, K.; Metsäpelto, R.-L.; Laakso, M.-L.; Sevón, E.; Verhoef-van Dorp, M. Parental working time patterns and children's socioemotional wellbeing: Comparing working parents in Finland, the United Kingdom, and the Netherlands. Child. Youth Serv. Rev. 2017, 76, 133-141. [CrossRef]

157. Vasankari, T.; Kolu, P.; Kari, J.; Pehkonen, J.; Havas, E.; Tammelin, T.; Jalava, J.; Koski, H.; Pihlainen, K.; Kyröläinen, H.; et al. Liikkumattomuuden Lasku Kasvaa-Vähäisen Fyysisen Aktiivisuuden ja Heikon Fyysisen Kunnon Yhteiskunnalliset Kustannukset; [Costs of Physical Activity are Increasing-The Societal Costs of Physical Inactivity and Poor Physical Fitness]; Publications of the Government's Analysis, Assessment and Research Activities 31/2018; Prime Minister's Office: Helsinki, Finland, 2018; Available online: http:/ /julkaisut.valtioneuvosto.fi/bitstream/ handle/10024/160724/31-2018-Liikkumattomuuden\%20lasku\%20kasvaa.pdf?sequence=1\&isAllowed=y (accessed on 1 June 2018).

158. Kalman, M.; Inchley, J.; Sigmundova, D.; Iannotti, R.J.; Tynjälä, J.; Hamrik, Z.; Haug, E.; Bucksch, J. Secular trends in toderate-to-vigorous physical activity in 32 countries from 2002 to 2010: A cross-national perspective. Eur. J. Public Health 2015, 25, 37-40. [CrossRef] [PubMed]

159. Aira, T.; Kannas, L.; Tynjälä, J.; Villberg, J.; Kokko, S. Hiipuva Liikunta Nuoruusiassa. Drop Off-Ilmion Aikatrendeja ja Kansainvalista Vertailua WHO-Koululaistutkimuksen (HBSC-Study) Aineistolla 1986-2010; [Diminishing Physical Activity in Adolescence. The Time Trends and International Comparisons of the Drop-Off Phenomena in the 1986-2010 Data of Health Behavior in School-Aged Children Study]; Publications of Research Center for Health Promotion at University of Jyväskylä: Jyväskylä, Finland, 2013; Available online: https:/ /jyx.jyu.fi/bitstream/handle/ 123456789/41670/978-951-39-5261-7.pdf?sequence=1\&isAllowed=y (accessed on 1 June 2018).

160. LIITU. The Physical Activity Behaviours of Children and Adolescents in Finland, Results of the LIITU Study; Kokko, S., Mehtälä, A., Eds.; Publications of the National Sports Council; National Sports Council: Helsinki, Finland, 2016; pp. 90-95. Available online: http://www.liikuntaneuvosto.fi/files/438/LIITU_2016.pdf (accessed on 30 May 2018).

161. Nuutinen, T.; Roos, E.; Ray, C.; Villberg, J.; Välimaa, R.; Rasmussen, M.; Holstein, B.; Godeau, E.; Beck, F.; Léger, D.; et al. Computer use, sleep duration and health symptoms: A cross-sectional study of 15-year olds in three countries. Int. J. Public Health 2014, 59, 619-628. [CrossRef] [PubMed]

162. Crawford, K. Schooling, citizenship and the myth of the meritocracy. Citizensh. Soc. Econ. Educ. 2010, 9, 3-13. [CrossRef]

163. Ministry of Social Affairs and Health. Child Welfare Act. (No. 417/2007; Amendments up to 1292/2013 included). Finlex Data Bank (Unofficial Translation). Ministry of Social Affairs and Health, 2007. Available online: https:/ /www.finlex.fi/fi/laki/kaannokset/2007/en20070417.pdf (accessed on 15 June 2018).

164. Finland's Ministry of Justice. Basic Education Act. Finlex Data Bank, 1998. Available online: https:/ / www. finlex.fi/en/laki/kaannokset/1998/en19980628.pdf (accessed on 29 May 2018).

165. World Commission on Environment and Development (WCED). Our Common Future; WCED for UN: Oslo, Norway, 1987; Available online: http:/ / www.un-documents.net/our-common-future.pdf (accessed on 20 January 2018). 
166. United Nations Conference on Environment and Development (UNCED). The Rio Declaration on Environment and Development; UNCED: Rio de Janeiro, Brazil, 1992; Available online: http:/ / www.unesco.org/education/ pdf/RIO_E.PDF (accessed on 15 September 2017).

167. Elkington, J. Towards the sustainable corporation: Win-win-win business strategies for sustainable development. Calif. Manag. Rev. 1994, 36, 90-100. [CrossRef]

168. Elkington, J. Cannibals with Forks-The Triple Bottom Line of 21st Century Business; Capstone Publishing Ltd.: Oxford, UK, 1997.

169. Elkington, J. Triple bottom line revolution: Reporting for the third millennium. Aust. CPA 1999, 69, 75-77.

170. Dillard, J.; Dujon, V.; Brennan, E.M. Introduction to Social Sustainability. In Social Sustainability: A Multilevel Approach to Social Inclusion; Dujon, V., Dillard, J., Brennan, E.M., Eds.; Routledge: New York, NY, USA, 2013; pp. 1-12.

171. Åhman, H. Social sustainability—Society at the intersection of development and maintenance. Local Environ. 2013, 18, 1153-1166. [CrossRef]

172. Vallance, S.; Perkins, H.C.; Dixon, J.E. What is social sustainability? A clarification of concepts. Geoforum 2011, 42, 342-348. [CrossRef]

173. Widok, A. Social Sustainability: Theories, Concepts, Practicability; EnviroInfo 2009; Shaker Verlag: Berlin, Germany, 2009; Available online: http:/ / enviroinfo.eu/sites/default/files/pdfs/vol122/0043.pdf (accessed on 13 May 2018).

174. Dillard, J.; Dujon, V.; King, M.J. Introduction. In Understanding the Social Dimension of Sustainability; Dillard, J., Dujon, V., King, M.C., Eds.; Routledge: Abingdon, UK, 2009; pp. 1-12.

175. Colantonio, A. Measuring Social Sustainability: Best Practice from Urban Renewal in the EU; International Land Markets Group, Report No. 2008/02: EIBURS Working Paper; Oxford Institute for Sustainable Development: Oxford, UK, 2008; Available online: http:/ / oisd.brookes.ac.uk/sustainable_communities / resources/SocialSustainabilityProspectspaper.pdf (accessed on 15 August 2017).

176. Willis, P.; McKenzie, S.; Harris, R. Introduction: Challenges in adult and vocational education for social sustainability. In Rethinking Work and Learning: Adult and Vocational Education for Social Sustainability; Willis, P., McKenzie, S., Harris, R., Eds.; Springer: Dordrecht, The Netherlands, 2009; pp. 1-11.

177. Wissenburg, M.L.J. Political Pluralism and the State: Beyond Sovereignty; Routledge: New York, NY, USA, 2008.

178. Koning, J. Social Sustainability in a Globalizing World: Context, Theory and Methodology Explored. In More on MOST: Proceedings of An Expert Meeting; UNESCO: The Hague, The Netherlands, 2002; pp. 63-89.

179. Boström, M. A missing pillar? Challenges in theorizing and practicing social sustainability: Introduction to the special issue. Sustain. Sci. Pract. Policy 2012, 8, 3-14. [CrossRef]

180. Weingaertner, C.; Moberg, Å. Exploring social sustainability: Learning from perspectives on urban development and companies and products. Sustain. Dev. 2014, 22, 122-133. [CrossRef]

181. Missimer, M.; Robèrt, K.-H.; Broman, G. A strategic approach to social sustainability-Part 1: Exploring the social system. J. Clean. Prod. 2017, 140, 32-41. [CrossRef]

182. Hawkes, J. The Fourth Pillar of Sustainability: Culture's Essential Role in Public Planning; Common Ground P/L.: Melbourne, Australia, 2001.

183. Nurse, K. Culture as the fourth pillar of sustainable development. Small States Econ. Rev. Basic Stat. 2007, 11, 28-40. [CrossRef]

184. Soini, K.; Dessein, J. Culture-sustainability relation: Towards a conceptual framework. Sustainability 2016, 8, 167. [CrossRef]

185. Axelsson, R.; Angelstam, P.; Degerman, E.; Teitelbaum, S.; Andersson, K.; Elbakidze, M.; Drotz, M.K. Social and cultural sustainability: Criteria, indicators, verifier variables for measurement and maps for visualization to support planning. Ambio 2013, 42, 215-228. [CrossRef] [PubMed]

186. Adams, W.M. The Future of Sustainability: Re-Thinking Environment and Development in the Twenty-First Century; IUCN: Gland, Switzerland, 2006; Available online: http:/ / cmsdata.iucn.org/downloads/iucn_future_of_ sustanability.pdf (accessed on 15 March 2018).

187. Pfahl, S. Institutional sustainability. Int. J. Sustain. Dev. 2005, 8, 80-96. [CrossRef]

188. Mathieson, J.; Popay, J.; Enoch, E.; Escorel, S.; Hernandez, M.; Johnston, H.; Rispel, L. Social Exclusion: Meaning, Measurement and Experience and Links to Health Inequalities: A Review of Literature. WHO Social Exclusion Knowledge Network Background Paper 1. 2008. Available online: http:/ / www.who.int/social_determinants / media/sekn_meaning_measurement_experience_2008.pdf.pdf (accessed on 30 May 2018). 
189. Peattie, K. Developing and delivering social science research for sustainability. In Researching Sustainability: A Guide to Social Science Methods, Practice and Engagement; Blyton, P., Franklin, A., Eds.; Earthscan: Adingdon, UK, 2011; pp. 17-33.

190. Sachs, I. Social sustainability and whole development. In Sustainability and the Social Sciences; Becker, E., Jahn, T., Eds.; Zed Books and UNESCO: New York, NY, USA, 1999; pp. 25-36.

191. Polese, M.; Stren, R. The social sustainability of cities; University of Toronto Press: Toronto, ON, Canada, 2000.

192. Biart, M. Social sustainability as part of the social agenda of the European community. In Soziale Nachhaltigkeit: Von der Umweltpolitik zur Nachhaltigkeit? Ritt, T., Ed.; Informationen zur Umweltpolitik 149; Arbeiterkammer Wien: Wien, Austria, 2002; pp. 5-10.

193. Littig, B.; Griessler, E. Social sustainability: A catchword between political pragmatism and social theory. Int. J. Sustain. Dev. 2005, 8, 65-79. [CrossRef]

194. Brand, J.E. The far-reaching impact of job loss and unemployment. Ann. Rev. Sociol. 2015, 41, 359-375. [CrossRef] [PubMed]

195. Brand, J.E.; Burgard, S.A. Job displacement and social participation over the lifecourse: Findings for a cohort of joiners. Soc. Forces 2008, 87, 211-242. [CrossRef] [PubMed]

196. Sen, A. Social Exclusion: Concept, Application, and Scrutiny; Social Development Papers No. 1; Asian Development Bank: Manila, Philippines, 2000; Available online: https:/ /www.adb.org/sites/default/files/publication/ 29778/social-exclusion.pdf (accessed on 30 May 2018).

197. Cowley, P.; McLaughlin, E.; Servey, A.D. Justice matters: Integrating the triple bottom line for business students, people, planet and profit. Int. J. Educ. Soc. Sci. 2017, 4, 13-17.

198. Laine, M. Culture in sustainability-Defining cultural sustainability in education. Discourse Commun. Sustain. Educ. 2016, 7, 52-67. [CrossRef]

199. Mills, M.; McGregor, G.; Baroutsis, A.; Te Riele, K.; Hayes, D. Alternative education and social justice: Considering issues of affective and contributive justice. Crit. Stud. Educ. 2016, 57, 100-115. [CrossRef]

200. Melendro, M.; Montserrat, C.; Iglesias, A.; Cruz, L. Effective social education of exclusion: Contributions from social pedagogy. Eur. J. Soc. Work 2016, 19, 931-945. [CrossRef]

201. Lundegård, I.; Wickman, P.-O. It takes two to tango: Studying how students constitute political subjects in discourses on sustainable development. Environ. Educ. Res. 2012, 18, 153-169. [CrossRef]

202. Kopnina, H.; Cherniak, B. Neoliberalism and justice in education for sustainable development: A call for inclusive pluralism. Environ. Educ. Res. 2016, 22, 827-841. [CrossRef]

203. Sund, L. Facing global sustainability issues: Teachers' experiences of their own practices in environmental and sustainability education. Environ. Educ. Res. 2016, 22, 788-805. [CrossRef]

204. Council of Europe. The Maastricht Global Education Declaration-A European Strategy Framework for Improving and Increasing Global Education in Europe to the Year 2015; Global Education Network Europe: Maastricht, The Netherlands, 2002; Available online: https://gene.eu/wp-content/uploads/Gene_ EuropeanPolicyFrameworks-TheMaastrichtDeclaration2002.pdf (accessed on 15 April 2018).

205. Habibullah, S.; Ashraf, J. Factors affecting academic performance of primary school children. Pak. J. Med. Res. 2013, 52, 47-52.

206. OECD. Low-Performing Students: Why They Fall Behind and How to Help Them Succeed; PISA; OECD Publishing: Paris, France, 2016.

207. Banerjee, P.A. A systematic review of factors linked to poor academic performance of disadvantaged students in science and maths in schools. Cog. Educ. 2016, 3, 1178441. [CrossRef]

208. Alexander, K.L.; Entwisle, D.R.; Horsey, C.S. From first grade forward: Early foundations of high school dropout. Sociol. Educ. 1997, 70, 87-107. [CrossRef]

209. Ingrum, A. High School Dropout Determinants: The Effect of Socioeconomic Status and Learning Disabilities. Honors Projects, Paper 24. Available online: https://digitalcommons.iwu.edu/econ_honproj/ 24/ (accessed on 30 May 2018).

210. Diemer, M.A.; Blustein, D.L. Vocational hope and vocational identity: Urban adolescents' career development. J. Career Assess. 2007, 15, 98-118. [CrossRef]

211. Ali, S.R.; McWhirter, E.H.; Chronister, K.M. Self-efficacy and vocational outcome expectations for adolescents of lower socioeconomic status: A pilot study. J. Career Assess. 2005, 13, 40-58. [CrossRef]

212. Sirin, S.R. Socioeconomic status and academic achievement: A meta-analytic review of research. Rev. Educ. Res. 2005, 75, 417-453. [CrossRef] 
213. Babajanian, B.; Hagen-Zanker, J. Social Protection and Social Exclusion: An Analytical Framework to Assess the Links; ODI Background Notes; The Overseas Development Institute: London, UK, October 2012; Available online: https://www.odi.org/sites/odi.org.uk/files/odi-assets/publications-opinion-files/7864. pdf (accessed on 1 May 2018).

214. Bernelius, V.; Vaattovaara, M. Choice and segregation in the 'most egalitarian' schools: Cumulative decline in urban schools and neighbourhoods of Helsinki, Finland. Urban Stud. 2016, 53, 3155-3171. [CrossRef]

215. Boyer, R.H.W.; Peterson, N.D.; Arora, P.; Caldwell, K. Five approaches to social sustainability and an integrated way forward. Sustainability 2016, 8, 878. [CrossRef]

216. Sparkes, J.; Glennerster, H. Preventing social exclusion: Education's contribution. In Understanding Social Exclusion; Hills, J., Le Grand, J., Piachaud, D., Eds.; Oxford University Press: New York, NY, USA, 2002; pp. 178-201.

217. Hills, J.; Le Grand, J.; Piachaud, D. Understanding Social Exclusion; Oxford University Press: New York, NY, USA, 2002.

218. Ministry of Justice. The Constitution of Finland 11 June 1999 (731/1999, Amendments up to 1112/2011 Included). Finlex Data Bank (Unofficial Translation). Ministry of Justice Finland, 1999. Available online: https:/ / www.finlex.fi/en/laki/kaannokset/1999/en19990731_20111112.pdf (accessed on 12 June 2018).

(C) 2018 by the authors. Licensee MDPI, Basel, Switzerland. This article is an open access article distributed under the terms and conditions of the Creative Commons Attribution (CC BY) license (http:/ / creativecommons.org/licenses/by/4.0/). 